\begin{tabular}{|c|c|c|c|}
\hline Article Info & \multicolumn{2}{|c|}{\begin{tabular}{l|l} 
RESEARCH ARTICLE & ARAŞTIRMA MAKALESİ
\end{tabular}} & \\
\hline Title of Article & \multicolumn{2}{|c|}{$\begin{array}{c}\text { Environmental Quality Impacts of } \\
\text { Industrial Areas within Residential Areas: } \\
\text { Sample of Konya Sugar Factory }\end{array}$} & \\
\hline $\begin{array}{l}\text { Corresponding } \\
\text { Author }\end{array}$ & \multicolumn{2}{|c|}{$\begin{array}{l}\text { Fadim YAVUZ } \\
\text { Necmettin Erbakan Üniversitesi, Güzel Sanatlar ve Mimarlık Fakültesi, Şehir ve Bölge } \\
\text { Planlama Bölümü, fadimyavuz@erbakan.edu.tr }\end{array}$} & \\
\hline $\begin{array}{l}\text { Received Date } \\
\text { Accepted Date }\end{array}$ & \multicolumn{2}{|l|}{$\begin{array}{l}06 / 10 / 2020 \\
12 / 05 / 2021\end{array}$} & \\
\hline DOI Number & \multicolumn{2}{|c|}{ https://doi.org/10.35674/kent. 806362} & \\
\hline Author / Authors & Fadim YAVUZ & ORCID: 0000-0002-8324-4662 & \\
\hline How to Cite & \multicolumn{2}{|c|}{$\begin{array}{l}\text { YAVUZ, F. (2021). Kent İçi Sanayi Alanlarının Çevresel Kaliteye Etkileri: Konya } \\
\text { Şeker Fabrikası Örneği, Kent Akademisi, Volume, 14, Issue 2, Pages, 278-299 }\end{array}$} & $\begin{array}{l}\text { Kent Akademisi } \\
\text { Urban Academy } \\
\text { ISSN /: E-ISSN } \\
\text { ISSN 2146-9229 }\end{array}$ \\
\hline
\end{tabular}

\title{
Kent İçi Sanayi Alanlarının Çevresel Kaliteye Etkileri: Konya Şeker Fabrikası Örneği
}

\begin{abstract}
:
Problem: In addition to the economic benefits, they offer to the city, region and country economy, industrial areas may also confront micro regions and/or cities with some environmental problems. Konya Sugar Factory, which became an industrial area within the city with the increase of population, caused various environmental and social problems that could reduce the environmental quality in its close vicinity and thus the quality of life of the city dwellers despite its substantial economic contributions to the city, region and country. Objective: This article explores the effects of Konya Sugar Factory on the city and urban dwellers in the context of environmental quality from the perspective of the inhabitants living in the immediate vicinity of the factory area. Method: In this context, a comprehensive questionnaire was carried out to determine comparatively the level of attention of the people living in the vicinity of the factory. Findings and Results: The findings indicate that the air quality in the immediate vicinity of the area is very low, the participants have a lot of environmental disturbances (air, noise, environmental and visual pollution, etc.) and health concerns. Additionally, it is deemed necessary to move the sugar factory out of the city due to its negative effects on the environment and to transform the area for the public benefit. The study may contribute to the managers and the planning authorities in eliminating the negative effects of Konya Sugar Factory on environmental quality.
\end{abstract}

KEYWORDS: Environmental quality, environmental pollution, Konya Sugar Factory, industrial areas within residential areas, location selection

${ }^{1}$ Necmettin Erbakan University, Fine Arts and Architecture Faculty, Department of Urban and Regional Planning, fadimyavuz@erbakan.edu.tr 


\section{ÖZ:}

Problem: Sanayi alanları kent/bölge/ülke ekonomisine yönelik sundukları ekonomik faydaların yanı sıra mikro bölgeleri ve/veya kentleri bir takım çevre sorunları ile de karşı karşıya bırakabilmektedir. Konya Şeker Fabrikası 1954 yılından günümüze kadar sadece Konya kenti ölçeğinde değil bölgesel ve ulusal ölçekte ekonomik büyüme, istihdam ve iş firsatları gibi birçok başarıya yol açmıştır. Fakat kurulduğu dönemde yerleşimlerden uzak bir konumda iken kentteki nüfus/kentsel yerleşik alan artışı beraberinde kent içi bir sanayi alanı haline gelen fabrika alanı aynı zamanda yakın çevresinde çevresel kaliteyi, dolayısıyla kentlinin yaşam kalitesini düşürebilecek çeşitli çevresel ve sosyal sorunlara da yol açmıştır. Amaç: Bu makale Konya Şeker Fabrikası'nın çevresel kalite bağlamında kente ve kentliye etkilerini fabrika alanının yakın çevresinde yaşayan yerleşik halkın perspektifinden araştırmaktadır. Yöntem: Bu bağlamda halkın fabrika kaynaklı sorunları önemseme düzeylerini, çevresel kalite sorunlarını bertaraf etme amacıyla fabrika alanının kentten uzaklaştırılması önerisine ilişkin yaklaşımlarını ve alanın sanayi işlevini yitirmesi halinde kamu yararı doğrultusunda kazanabileceği yeni işlev önerilerini mahalleler bazında karşılaştırmalı belirlemeyi amaçlayan kapsamlı bir anket uygulaması gerçekleştirilmiştir. Bulgu ve Sonuçlar: Bulgular katılımcıların; (1) fabrikanın ekonomik faaliyetlerinden genelde memnun olduklarını, (2) ancak alanın yakın çevresinde hava kalitesinin çok düşük olduğunu, (3) katılımcıların fabrika alanından kaynaklı çevresel rahatsızlıklarının (hava, gürültü, çevre ve görüntü kirliliği vb.) ve sağlık kaygılarının oldukça fazla olduğunu, (4) pek çok insana iş imkânı sağlamasına karşıı şeker fabrikasının çevreye olan olumsuz etkileri nedeniyle şehir dışına çıkarılmasının katılımcılar tarafından gerekli görüldüğünü, (5) bu durumda âtıl kalacak alanın kamu yararına (sosyo-kültürel alan, üniversite alanı, festival/fuar alanı, park, ağaçlandırılacak alan vb.) düzenlenmesinin istendiğini göstermektedir. Bu çalışma Konya Şeker Fabrikası'nın çevresel kaliteye olumsuz etkilerini bertaraf etmede yöneticilere ve planlama otoritelerine katkı sağlayacak niteliktedir.

ANAHTAR KELIMELER: Çevresel kalite, çevresel kirlilik, Konya Şeker Fabrikası, kent içi sanayi alanları, yer seçimi

\section{“Kent İçi Sanayi Alanlarının Çevresel Kaliteye Etkileri: Konya Şeker Fabrikası Örneği”}

\section{GíRiş:}

Kentsel yerleşmelerin sosyo-ekonomik gelişiminde, önem kazanmasında veya önemini kaybetmesinde yerel ve bölgesel konum özellikleri olduğu kadar kentin sahip olduğu ekonomik fonksiyonların gelişim ve değişim süreci de önem arz etmektedir. Zamanla bu fonksiyonlar çevreyi ekonomik ve mekânsal olarak yönlendiren bir yapı da oluşturmaktadırlar (Ünal \& Yücel, 2017). Ekonomik gelişmenin bir bileşeni olan sanayi alanları kentlerin gelişimi, teknolojik ilerleme, ekonomik kazanımlar gibi getiriler açısından kentler için vazgeçilmez unsurlardır (Kaya ve ark., 2015). Değişen üretim dinamikleri ve mekân gereksinimleri doğrultusunda kentler gelişmekte ve büyümektedir. Sanayileşme toplumda işgücü ve kentsel altyapının organizasyonunda büyük bir değişime yol açmıştır. Herhangi bir sanayi alanı işçilerin çalışması için büyük üretim alanlarını ve bu üretim alanlarının işletilmesi için gerekli yardımcı personeli gerektirmekte, devamında bu insan topluluğuna bağlı olarak bölgede toplanan hizmetler sektörü sanayi alanları yakın çevresinde ve kentte nüfusunun hızlı bir şekilde artmasına yol açmaktadır (Zeren \& Kılınç Savrul, 2012). Sanayi yatırımları ise kentsel kullanımları çekici bir unsur olması nedeniyle kentlerin gelişme yönlerini belirlemede, dolayısıyla kent makroformunu şekillendirmede etkili olmaktadır.

Sanayi işletmelerinin yer seçiminde ve kentteki dağılış düzeninde ucuz kuruluş maliyeti, ulaşım olanakları, hammadde, pazar ve işgücüne yakınlık, yerel otoritelerin tutumu gibi yerel olumlu özelliklerin etkisinin olduğu kabul edilmektedir. Günümüzde etkili haberleşme ve ulaşım imkânları ile ileri bilgi teknolojilerine bağlı olarak sanayi yer seçimi kısıtlılıkları azalmakla birlikte, çevresel kaygılar gerek yer seçim aşamasında gerekse üretim aşamasında sanayi alanlarının değişmez öncelikli alanı niteliğinde olmalıdır. Uzun yıllar metropoliten kentler sanayi yatırımcıları için çekim merkezi olmuştur. Ancak, sanayi yatırımlarının hızla arttığı, gelişmelerin plan dâhilinde olmadığı metropoliten kentlerde, problemler ortaya çıkmakta ve merkezlerde yığılmalar sonucu mekânsal çözümlemeleri yetersiz kalan sağlıksız ve kimliksiz kentler oluşmaktadır (Kanbak, 2013; Yüzer \& Giritlioğlu, 2003). Özellikle kent içinde yer seçmiş veya kent dışında kurulmuş iken kentlerin dinamik büyüme süreçlerinde kentsel nüfusun ve buna bağlı kentsel alan kullanımının hızla büyümesiyle kent içinde kalmış sanayi alanları, gerekli tedbirler alınmadığı sürece yakın konumdaki konut alanlarında yaşayanlar ağırlıklı olmak üzere kenti ve kentliyi sosyal-ekonomik ve çevresel bağlamda olumsuz etkileyebilmektedir. Yerleşim alanları içerisinde kalan sanayi alanlarından kaynaklı bu olumsuzluklardan çevresel kalitenin azalması ise sosyal ve ekonomik sonuçları da olan önemli bir sorunsaldır. Bu nedenle sanayi alanlarına ilişkin 
konum ve faaliyet özellikleri doğrudan veya dolaylı olarak yaşamı ve yaşam kalitesini etkilemesi nedeniyle kritik konulardır.

20. yüzyılın ikinci yarısından itibaren teknolojik gelişmelere paralel olarak değişim gösteren sanayi yapılanmaları, üretimin kentlerin dışında yer alması fikrini ortaya koymuş ve kent içinde işlevsizleşen sanayi alanlarının değerlendirilmeleri gündeme gelmiştir (Kaya ve ark., 2015). Sanayileşmeye bağlı kentlerde gözlenen çevresel sorunlar ortaya çıkarması ve mekânsal olarak sanayi alanların kentsel gelişmeleri zorlaması sanayi alanlarının kent merkezlerinden kent çeperinde yer seçmeleri süreci ve organize sanayi bölgeleri yaklaşımının benimsenmesi ile sonuçlanmıştır (Yaman, 2005).

Bu çalışmada Konya kentinde 1954 yılından itibaren şeker üretimi gerçekleştiren, kurulduğu dönemde yerleşimlerden uzak bir konumda iken kentteki nüfus/kentsel yerleşik alan artışı beraberinde kent içi bir sanayi alanı haline gelen, bu duruma bağlı yakın çevresinde hava kirliliği, görsel kirlilik, gürültü kirliliği vb. olumsuz etkileri ile konumu kent gündeminde sıklıkla tartışılagelen Konya Şeker Fabrikası'nın çevresel kalite bağlamında kente ve kentliye etkileri halkın perspektifinden araştırılmaktadır. Bu amaç doğrultusunda kapsamlı bir anket çalışması ile fabrika alanına (noktasal kirlilik kaynağına) yakın konumdaki yerleşik halkın; bulunulan çevreden memnuniyet, fabrika alanının kendileri için arz ettiği önem, fabrikadan kaynaklı hava, gürültü, çevre ve görüntü kirliliği vb. olumsuzluklara yönelik farkındalıkları, bu olumsuz etkilerin alandaki çevresel kalite/yaşanabilirliğe etkileri, fabrika alanının kent dışına taşınmasına yönelik görüşleri ve bu durumda atıl kalacak alana verilebilecek fonksiyon önerilerini örneklem mahalleler bazında karşılaştırmalı olarak elde etmek amaçlanmıştır.

Bu kapsamda çalışma 4 bölümden oluşmaktadır: "Giriş" bölümünde; çevresel kalite kavramı, sanayi alanları ve kentleşme ilişkisi, sanayi kaynaklı sorunlar ve kent içi sanayi alanlarına yönelik güncel planlama yaklaşımları ilgili literatür çerçevesinde ele alınmış; çevresel kalite çerçevesinde Konya'da yerleşim alanları içerisinde kalan sanayi alanları değerlendirilmiştir. "Yöntem" bölümünde; Konya Şeker Fabrikası'nı tanıtıcı bilgiler, örneklem alanı ve saha çalışmasının genel çerçevesi tanımlanmıştır. "Araştırma Bulguları" kısmında; halkın fabrika alanının kente/kentliye etkileri hakkındaki görüşleri sunulmuştur. "Değerlendirme ve Sonuç" kısmında ise; araştırma sonuçları ile bulguların planlama pratiği için önemi açıklanmış ve önerilerde bulunulmuştur.

\section{Kent İçi Sanayi Alanları ile Çevresel Kalite İlişkisinin Değerlendirilmesi}

\section{1. Çevresel Kalite kavramı}

Şehirler çevresel olarak sağlıklı ve sosyal olarak kabul edilmiş yaşam ortamlarını çeşitli şekillerde sağlarlar, ancak şehir sakinlerinin refahını ciddi şekilde etkileyen kentleşme sorunları oluştururlar (Dissanayake ve ark., 2020). Yirminci yüzyıl sonlarında artan çevresel kirlilik, bozulan doğal ortamlar, küresel iklim değişiklikleri vb. sorunlar karşısında sürdürülebilir bir gelişmenin gerekliliği ortaya konulmuş ve bunun çıkış noktasının kentler olduğu kabul edilmiştir (Dede \& Şekeroğlu, 2019).

Çevresel boyut, yaşam kalitesi üzerindeki en önemli etkilerden biri olup bu etki çevresel kalite, çevreye duyarlı davranış ve çevresel hizmetlerin tüketimi göstergelerinin uygulanması ile değerlendirilebilir. Yaşam kalitesinin fiziksel çevre tarafından güçlü bir biçimde etkilenmesine bağlı olarak çevresel kalite insanların refahında anahtar bir faktördür (Streimikiene, 2015). Düşük kaliteli çevrelerde yaşamak, yenilenemeyen kaynaklar için daha fazla harcama ve gelecek nesiller için daha fazla çevresel yük anlamına gelmektedir. Ayrıca bireyler ve işletmeler üzerinde derin olumsuz etkilere (verimlilik kaybı, ekonomik kayıplar vb.) neden olabilir (Hsueh \& Lin, 2018).

Kentsel konfor bir mekânın veya yerin algılanan kalitesini veya karakterini tanımlayan ve onu sakinler için çekici kılan geniş bir terimdir. Kentsel olanakların rahatlığı, erişilebilirliği ve tasarımı bir bölgede yaşanan kentsel konfora yalnızca katkıda bulunan bir faktör iken kentsel konfor, algılanan gürültü seviyeleri, hava veya su kalitesi gibi çevresel faktörlerden ve topluluk duygusu gibi sosyo-kültürel unsurlardan da etkilenmektedir (Allen, 2016). Spesifik bir yaşam ortamında canlıların yaşamı üzerinde etkin olan kimyasal, fiziksel ve biyotik faktörlerin bütünlüğü olan çevrenin fiziksel ve kimyasal koşullarının yaşam alanlarına etkisi de büyüktür (Çelik ve ark., 2017).

Çevre, sağlık durumunu doğrudan etkiler; yaşam kalitesinde, sağlıklı yaşam süresinde ve sağlık eşitsizliklerinde önemli bir rol oynar. Kötü hava kalitesi, erken ölüm, kanser ve solunum ve kardiyovasküler sistemlerde uzun vadeli hasarla 
bağlantılıdır. Toksik ve kansere neden olan kimyasallar içeren ikinci el duman, sigara içmeyen yetişkinlerde kalp hastalığına ve akciğer kanserine katkıda bulunur. Küresel olarak, tüm ölümlerin yaklaşık \%25'i ve toplam hastalık yükü çevresel faktörlere bağlanmaktadır. Bu bağlamda güvenli hava, toprak ve su, sağlıklı bir toplum ortamı için çok önemlidir. İkinci el duman, karbon monoksit, alerjenler, kurşun ve toksik kimyasallar gibi tehlikesiz bir ortam, hastalıkların ve diğer sağlık sorunlarının önlenmesine yardımcı olur (ODPHP, 2020). Belirtilen gerekçelerle yaşam kalitesi değerlendirmesinde çevre koşulları (sıcaklık, nem, gürültü ve oksijen miktarı vb.) da göz önüne alınmaktadır (Çelik ve ark., 2017).

Literatürde (ACE, 2019; Leby \& Hashim, 2010; Lowe ve ark., 2013; Parkinson ve ark., 2006; Salihoğlu, 2016, Tapsuwan ve ark., 2018; Türkoğlu ve ark., 2006; Yeang, 2006) çevresel kalite bir yerin gürültülü veya sessiz oluşu, kirli veya temiz olması, kalabalık veya tenha olması, yapı kalitesinin iyi ya da kötü olması ile ilişkilendirilmektedir. Türkiye'de kentsel yaşam kalitesi göstergelerini analiz eden Sarı \& Kındap (2018) yaşanabilirlik bağlamında çevresel kalite değerlendirmesinde kullanılan göstergeleri "hava kalitesi, toplam partikül miktarı, içilebilir suya erişebilen nüfus oranı, kişi başına düşen sera gazı miktarı, hane halkı geri dönüşüm oranı, kişi başı yıllık katı atık miktarı, su kalitesi, gürültü kirliliğine maruz kalan nüfus oranı, karbon dioksit emisyon miktarı, emisyon miktarı, atıksu arıtma oranı, kişi başı yıllık toplanan atık miktarı" olarak tespit etmişlerdir. Krekel \& MacKerron (2020) doğal çevrenin bireysel ve toplumsal mutlulukta oynadığı temel rolün artan farkındalığını yansıtan çalışmalarında doğal bağışların miktarı ve zaman içindeki değişimleri ile çevre kalitesi ve kirlilik, iklim değişikliği ve diğer faktörlerden kaynaklanan küresel ve yerel çevre kalitesindeki değişikliklerle belirlenen doğal çevreye odaklanmışlardır. Bu bağlamda çevre kalitesinin nasıl hissettiğimiz ve hayatlarımızı nasıl değerlendirdiğimize (yaşam memnuniyeti/kalitesi) olan doğrusal etkilerini ortaya koymuşlardır.

Çevre ve mutluluk/yaşam memnuniyeti arasındaki ilişkiye iki yönlü akademik ilgi söz konusu olmuştur (Krekel \& MacKerron, 2020): Birincisi, çevrenin insanların öznel refahını nasıl etkilediğine, ayrıca öznel refah göstergeleri ile kamuya açık ve fiyatlandırılamayan çevresel faktörleri parasal olarak değerlendirmeye yönelik çalışmalardır. İkinci grup çalışmalar ise çevre yanlısı davranışların insanların öznel refahını nasıl etkilediğine ve bunun karşılığında insanların duygusal durumlarının onları daha çevre dostu şekillerde davranmaya yönlendirmek için nasıl etkili bir şekilde kullanılabileceğine ilişkin çalışmalardır. Atkins ve ark. (2015) çevresel kaliteyi bir yerin ne kadar yaşanabilir olduğunu anlamada kullanılacak anahtar bir kavram olarak görmekte; çevresel kalitenin doğal ve yapılı çevreye ilişkin temiz su, temiz hava ile kirlilik, atık ve gürültü düzeyi vb. pek çok özellikle ölçülebileceğini vurgulamaktadır. Kentsel çevre kalitesini yapay çevre ve doğal çevre olarak ikiye ayıran Li ve ark. (2016) ise doğal kentsel çevre kalitesini, coğrafya, topografya, peyzaj, hava, toprak, gürültü, bitki örtüsü, hayvanlar vb. koşullar dahil olmak üzere topluluğun dayandığı doğal ortam olarak nitelemektedir. Doğal kentsel çevre kalitesi, sakinlerin yaşam biçimleri üzerinde kaçınılmaz etkilerde bulunmakta olup doğal kentsel çevre kalitesinde bazı istenmeyen koşullar söz konusu ise yapay iyileştirmelere ihtiyaç vardır (Hsueh \& Lin, 2018). Carmona \& Magalhaes (2009) yerel çevre kalitesini ölçmede göreceli bir şekilde olumlu ya da olumsuz biçimde deneyimlenen 12 unsur tanımlamıştır: temiz ve düzenli, erişilebilir, çekici, rahat, kapsayıcı, yaşamsal ve uygulanabilir, işlevsel, ayırt edici, güvenli, sağlam, yeşil ve kirletilmemiş olma ve işlevsellik. Salihoğlu (2016) ise çevresel kaliteyi "estetik, gürültü, bakımlılık, çevre temizliği, hava kirliliği, kalabalık hissi” göstergeleri ile tanımlamaktadır. Silva \& Mendes (2012) kentsel hava kirliliği ve kentsel gürültüyü şehirlerdeki yaşam kalitesini azaltan başlıca faktörler olarak değerlendirmişlerdir.

\section{1. Çevresel Kalite Çerçevesinde Kent İçi Sanayi Alanları}

Kalkınmanın ana sektörlerinden birisi olan sanayi ve çevre arasında çok yönlü ve karşıllıklı çok sıkı bir ilişki mevcuttur. Ancak, çevreyi korumaya dönük önlemlerin alınmaması ve uygun teknolojilerin kullanılmaması halinde çevre ve toplum üzerinde olumsuz sonuçlar getiren bir dengesizlik ortaya çıkmakta; kaynakların tahribi ve çevrenin hızla kirlenmesi ile sonuçlanmaktadır (Yaşar \& Şevik, 2003). Kentsel çevrede doğal çevre faktörlerinden hava-su-toprağın kirlenmesi en önemli sağlık sorunlarını da beraberinde getirmektedir (Dede \& Şekeroğlu, 2019). Hâkim rüzgâr yönü ve şiddeti, topografya vb. fiziki ölçütlerin yanında yerleşmeye ilişkin nüfus, gelişim özellikleri ve şehrin büyüme yönü öngörüsü vb. beşerî özelliklerin önemsenmemesine bağlı sanayi alanlarının yanlış seçimi kararları kenti ve kentliyi önemli olumsuzluklarla karşı karşıya bırakmaktadır (Çiftçi ve ark., 2013; Önder \& Konaklı, 2002).

Endüstriyel faaliyetler fosil yakıtların atmosfere salınmasına ve çevresel kalitenin düşmesine yol açmaktadır (Özgür Güler \& Börüban, 2019). Endüstri emisyonları, üretimde kullanılan maddelerin atmosfere atılmasından dolayı endüstri 
türüne bağlı özel bazı kirlilikler oluşturmakla birlikte, endüstriyel kirliliğin en önemli kaynağı, bazı özel haller dışında, tesislerde kullanılan yakıt kaynaklı kirleticiler olmaktadır. Ayrıca, endüstri alanlarının çevreye etkileri baca yüksekliğine bağlı olarak da değişebilmektedir. Alçak bacalı endüstri alanları tesis yöresinde yoğun kirliliğe sebep olmakta, kirletici etkiler tesisten uzaklaştıkça hızla azalmaktadır. Lokal kirlilik problemlerine çözüm olarak yapılan yüksek bacalardan bırakılan endüstriyel kirleticiler ise daha uzak mesafelerde kirliliğe sebep olmaktadır (Çitçi ve ark., 2013). Kentin büyüme yönü göz önünde bulundurulmadığı için sanayi alanı kent içinde kalmakta, hava kirlenmekte, arazi düzensiz şekilde işgal edilmekte, görsel kirlilik ve gürültü artmakta, trafik sıkışmakta ve doğal kaynaklar tahrip edilerek zarar görmektedir (Önder \& Konaklı, 2002). Bu sorunların yanı sıra dünyanın birçok bölgesinde hızlı endüstriyel gelişmeye bağlı sanayi bölgelerindeki topraklarda ağır metal kirliliği konusunda potansiyel insan sağlığı riskleri nedeniyle artan bir kamuoyu endişesi vardır (Mohammadi ve ark., 2020). Kent merkezleri gibi trafiğin yoğun olduğu bölgelerde ağır metal kirliliğinin oldukça yüksek olduğu bilinmektedir. Endüstriyel faaliyetlerden sonra giderek artan hava kirliliği ve ağır metal kirliliği büyük önem taşımaktadır. Doğada kolayca çözünmeyen ağır metaller canlı organizmalarda biyolojik olarak birikme eğilimindedirler. Bazı ağır metaller ise düşük konsantrasyonlarda bile toksik veya kanserojen etkiye sahiptir (Koç, 2021).

Yerleşim alanları içerisinde kalan sanayi alanlarının kente ve kentliye olan olumsuz çevresel, sosyal ve uzun vadede ekonomik olumsuzluklarının yanı sıra kentlerde nüfusun ve kentsel arazi değerinin her geçen gün artması karşısında, kent içinde yer alan sanayi alanlarının konumlarının değerli olması, fazlaca ihtiyaç duyulan yeşil alan, sosyo-kültürel etkinlik vb. kullanımlar için elverişli mekânlar olmaları vb. potansiyelleri bu alanların sürdürülebilir kent kavramı ile yeniden programlanarak kullanılmalarını gerekli kılmaktadır (Tolga, 2006'dan aktaran Kaya ve ark., 2015). Üretimin kentlerden uzaklaşmasıyla kent içinde kalan sanayi alanları, kentlerin yeniden yapılanma sürecinde yeni kullanım biçimleriyle önemli bir rol üstlenmişlerdir. Kent dışına çıkarılan sanayi alanlarına sanayi işlevini kaybetmeleri sonrasında kamu yararı doğrultusunda yeniden işlev (dinlenme, eğlenme, spor, sosyo-kültürel alan vb.) verilerek kente ekonomik, görsel ve sosyal olarak katkı sağlamaları, çevresel kaliteyi dolayısıyla yaşam kalitesini artırmaları mümkün olabilmektedir (Kaya ve ark., 2015). Bu bağlamda günümüzde yükselen yeni ekonomik sektörlerin ve küresel ölçekte serbest dolaşım imkânı kazanan sermayenin kente çekilebilmesine yönelik yerel yönetimlerce işlevlerini kaybeden eski fabrika alanları, antrepo ve depo alanları, liman bölgeleri vb. alanlarının kent ekonomisine yeniden kazandırılması yoluyla kentsel refah ve yaşam kalitesinin arttırılmasının da amaçlandı̆̆ı görülmektedir (Altanlar ve ark., 2020).

\section{2. Çevresel Kalite Çerçevesinde Konya'da Kent İçi Sanayi Alanları}

Konya'da mevcut organize sanayi bölgelerinden 1.OSB yerleşim bölgesi içerisinde kalmakta, diğer OSB'ler ise şehir merkezine 20 km. uzaklıkta ancak, şehrin hâkim rüzgâr yönü olan Kuzey-Kuzey Doğu istikametinde kuruludur (Yaşar \& Şevik, 2003). Kent merkezinde yerleşim alanlarına yakın Meram Sanayii Sitesi, Krom Magnezit Fabrikası, Çimento Fabrikası ve Şeker Fabrikası vb. yerleşim alanı içerisinde kalan kirletici nitelikte sanayii türleri mevcuttur. Geniş arazi yapısına rağmen hava akımlarına açık bir yer olmayan Konya'da kış mevsiminde sisli, puslu ve rüzgâr hızının çok düşük olduğu günlerde havadaki kirlilik parametreleri hemen dağılmamaktadır. Hava kirliliğindeki artışa bağlı olarak hava kalitesi azalmaktadır (Kara ve ark, 2019).

Bu çalışmaya konu edilen Konya Şeker Fabrikası'nın kurulduğu dönemde yakın çevresi boş iken zamanla kent içinde kalmış ve bu durum beraberinde yakın çevresi için çevresel, sosyal ve fiziksel birtakım bazı sorunları meydana getirmiş̧ir. 1954-2011 yılları arasında yakıt olarak kömür ile çalışan Konya Şeker Fabrikası'nın yakın çevresinde yaşayan halk uzun yıllar yoğun duman ve ise bağlı hava kirliliğine maruz kalmıştır.

Konya'da 2003 yılında sanayide, 2004 yılında da konutlarda doğal gazın kullanılmaya başlanmasına karşın Konya Şeker Fabrikası'nda 2011 yılından itibaren elektrik üretiminde doğal gaz ile çalışan buhar kazanları kullanılmaya başlanmış olup; elde edilen buhar, elektrik ve ısıdan üretim sürecinde faydalanılmaktadır (Karyeyen ve ark., 2012).

Fabrikanın hammaddesi olan şeker pancarının işlenmesi esnasında ve neticesinde artık madde olan küspe kokusu fabrikanın aktif olarak çalıştı̆̆ çevresinde hammadde-ürün nakliyatı amaçlı yoğun bir araç trafiği söz konusu olmaktadır. Bu trafik yoğunluğu ise yaya ve taşıt güvenliğini olumsuz yönde etkilemektedir. Fabrika yakınında oturan halk fabrikaya hammadde getiren ve yem maddesine dönüştürülen küspeleri ve üretilen şekerleri fabrikadan taşıyan nakliye araçlarının (kamyon, tır vb.) sesinden rahatsız olabilmektedir. Ayrıca üretim esnasında da fabrikada ses düzeyi fazlaca gözlenmektedir. 
Konya Şeker Fabrikası'nın çevresine olan bu tür olumsuz etkilerini azaltmaya yönelik 15.03.2011 tarih ve 2011/02 sayılı Mahalli Çevre Kurulu kararı (Url 1) önem arz etmektedir. Bu bağlamda; "(1) Kömür kullanmaya hazır olan ve kullanılmadığı ifade edilen Stein Müller kazanları mühürlenerek tamamen devre dışı bırakılmasına, (2) WKV kazanında kömür ve doğalgaz birlikte kullanılmaktadır. Bu kazanda da kömür kullanımı tamamen sonlandırılmasına, (3) Doğalgaz kesintisi veya acil durumlar için Konya Büyükşehir Belediyesi'nin görüş ve bilgisi, Valilik Makamı'nın (İl Çevre ve Orman Müdürlüğ̈̈) izni ile tesis kömür kazanlarını kullanabilmesine, (4) Baca emisyonları için online izleme ağ kurarak Il Çevre ve Orman Müdürlüğ̈̈ ve Konya Büyükşehir Belediyesi'ne anlık izlemeye açılmasina, (5) Tesis deposunda doğalgaz kesintisine karşı acil durumlarda kullanılmak üzere belli oranda kömürü Valilik Makamı (İl Çevre ve Orman Müdürlüğ̈̈) ve Konya Büyükşehir Belediyesi'nin bilgisi dahilinde bulundurabilmesine, (6) Açıkta küspe taşınmasina hiçbir şekilde müsaade edilmemesine, (7) Demiryolu taşımacıllğı konusunda vermiş olduğu Taahhüdü 'nü Mahalli Çevre Kurulu kararında belirtilen süre içerisinde tamamlamasina, (8) Tesisten kaynaklanan koku emisyonlarının önlenmesi amaciyla; 04.09.2010 tarih ve 27692 Sayll Resmi Gazete'de yaylmlanan ancak 2012'de yürürlüğe girecek olan Kokuya Sebep Olan Emisyonların Kontrolü Yönetmeliği hükümlerinin yerine getirilmesinin sağlanmasina" karar verilmiştir.

Konya Şeker Fabrikası'nın aldığı çevresel diğer tedbirler ise; hava kirliliği için doğalgaz kazanında filtre yapılması, küspe kurutma ünitesinde partikülleri ve kirlilikleri tutucu özellikte sulu baca sisteminin kullanılması, kötü koku problemini çözmeye yönelik Gıda ve Tarım Üniversitesi'nin pancarı daha iyi havalandırma suretiyle içindeki mikrobiyolojik faaliyetleri dolayısıyla kötü koku oluşumunu engellemeyi amaçlayan çalışmaları, koku kaynakları için atıksu arıtım tesisinde yoğunlaştırma tankının üstünün kapatılması, fabrikadan kaynaklı gürülttü sorununu çözmeye (sınır değerlerin altında tutmaya) yönelik fabrika etrafının ağaçlandırılması, ses ile ilgili ölçümlerin yapılması olarak siralanabilir.

Günümüzde fabrikadan duman salınımı filtre önlemleri ile geçmişe göre nispeten azalmış olup, daha çok buhar salımı söz konusu olmaktadır. Dolayısıyla geçmişe göre göreli bir iyileşme (kurum ve isin azalması, küspelerin kapalı ortamda taşınması vb.) mevcuttur. Ancak fabrikadan kaynaklı rahatsız edici seviyedeki kötü koku, yoğun taşıt trafiği ve yaya güvenliği problemleri için henüz yeterli bir çözüm bulunamamıştır.

Bulunduğu kent için olduğu kadar bölge ve ülke ekonomisi için büyük önem arz eden, ancak sebebiyet verdiği çevresel sorunlarla da gündemde olan Konya Şeker Fabrikası'nın kent içinden kent dışına taşınması konusu da zaman zaman Mahalli Çevre Kurulu kararlarına konu olmuştur. Nitekim 29.01.2013 tarih ve 2013/01 sayılı Mahalli Çevre Kurulu kararında (Url 2) yer alan “Mahalli Çevre Kurulu'nun 02.08.2005 tarih ve 2005/08 sayıl kararına göre Konya Şeker Fabrikası'na ait İlimiz Meram İlçesi, Beyşehir Yolu Üzeri No:47 adresinde faaliyet gösteren Şeker Üretim Tesisinin faaliyetinin mevcut yerinde devam etmesi konusunun Konya Valiliği Çevre ve Şehircilik Il Müdürlüğ̈̈ ve Konya Büyükşehir Belediye Başkanlığı Çevre Koruma ve Kontrol Daire Başkanlı̆̆ tarafindan değerlendirilerek durumun Valilik Makamı ve Büyükşsehir Belediye Baş̧kanlığı Makamına sunulmasının ardından daha sonraki toplantıda karar verilmesine" ifadesi 2005 yılında dahi taşınma konusunun tartışıldığını göstermektedir. Bu toplantıdan sonraki toplantıda konunun ele alınmamış; geçen 7 yıl zarfinda herhangi bir taşınma faaliyeti gerçekleşmemiştir. Ancak fabrika alanının onaylı imar planlarında "sanayi" olan fonksiyonu 2043 plan yılı için hazırlanan (2016) Konya-Karaman Planlama Bölgesi 1/100.000 Ölçekli Master Planı'nda Konya Şeker Fabrikası Alanı doğusundaki park ve kamu alanları ile bütünleşecek şekilde yeşil alan olarak planlanmıştır (Şekil 1). Bu plan kararı bahsedilen Mahalli Çevre Kurulu kararlarının olumlu bir yansıması olarak değerlendirilebilir. Fabrikanın taşınmasının ise mali gerekçelerle ertelendiği, bu nedenle net bir taşınma tarihi verilmediği düşünülmektedir 


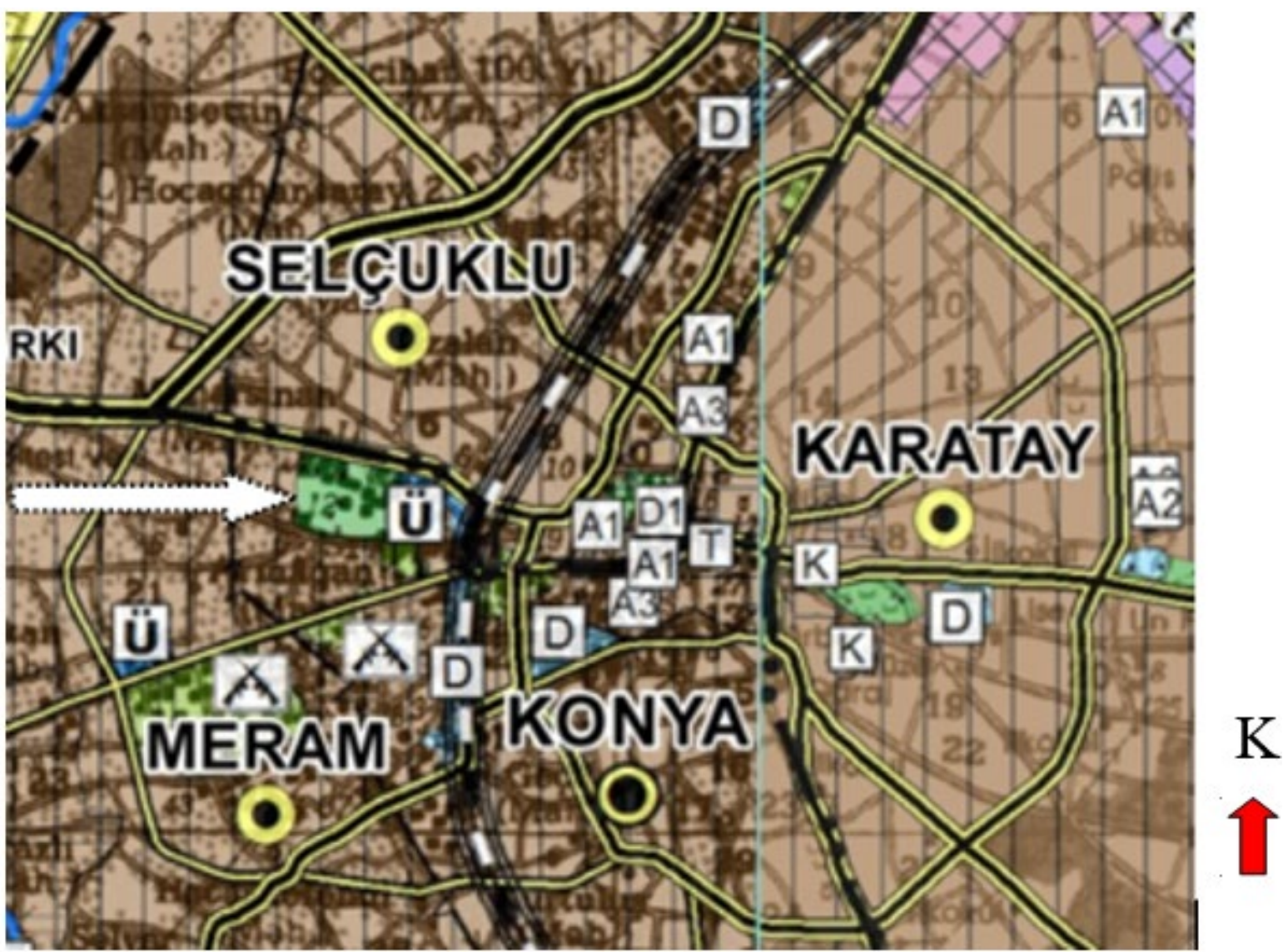

Şekil 1. Konya-Karaman Planlama Bölgesi 1/100.000 Ölçekli Master Planında Konya Şeker Fabrikası alanının yeni fonksiyonunu gösterir plan verisi (Konya Büyükşehir Belediyesi, 2016)

Bilimsel araştırmalar da yukarıda gözlemlerle özetlenen Konya Şeker Fabrikası'nın kente ve kentliye olan olumsuz etkilerini doğrulamaktadır. Çevre ve Şehircilik Bakanlığı hava kalitesi izleme istasyonlarından elde edilen verilere göre; atmosferinde en fazla PM10 bulunduran Konya ve (Konya Şeker Fabrikası'nın da içerisinde yer aldığı) Meram ilçesi en tehlikeli bölge olmuştur (Kara ve ark, 2019). Nitekim Yaşar \& Şevik (2003) il merkezinde tüketilen yakıtın 1/3'ini tüketen Konya Şeker Fabrikası'nın hava kirliliğine olumsuz katkısını vurgulamışlardır. Fabrika alanının güneyindeki yerleşmeler kentte hâkim kuzey-kuzeydoğu rüzgarlarına bağlı olarak hava kirliliğine maruz kalmaktadır. Önder ve ark. (2007) çalışmalarında Konya Şeker Fabrikası'nın da aralarında olduğu örneklem alanlarında fabrikaların etrafındaki yoğun trafik ve yerleşim alanlarında bazı ağır metallerin önemli bir kirlilik seviyesinde olduklarını tespit etmişlerdir. Hava kirliliği astım ve kardiyolojik rahatsızlıklara etki eden önemli bir etmen (Esen \& Toprak, 2017) iken, Konya'da coğrafi bilgi sistemi yardımıyla kalp ve solunum yolu hastalarının mekânsal dağılımını belirlemeyi amaçlayan Durduran \& Durduran (2009) üst solunum yolu hastalıklarının kent merkezinde ve kentin kuzeyine doğru yoğunlaştığını gözlemlemişler; bu durumu ise kent merkezinde kalan ve şehrin kuzeyinde yer alan sanayi alanlarından kaynaklı hava kirliliği ile ilişkilendirmişlerdir.

Gürültü doğal hayatı, çevresel kaliteyi, hoş görüntüyü ve insan sağlığını olumsuz yönde (stres, iş verimliliğini azaltma vb.) etkileyen, yaşanabilirliği azaltan önemli bir sorundur (Dalkılıç \& Dursun, 2019). Bu soruna ilişkin Dursun ve ark. (2006) Konya Şeker Fabrikası'na şeker pancarı, akaryakıt için kömür, hammadde getirmek ve şeker, yemek ve pancar döküntüsü (küspe) gibi fabrika ürünlerini uzaklaştırmak için şehir içi trafiğine kaçak yollarla giren ağır araçları kentteki gürültü artışının en önemli etkenleri olduğunu tespit etmişlerdir.

Konya kent merkezindeki görsel kirlenmeleri belirlemeyi amaçlayan Önder \& Konaklı (2002) sanayi alanlarını ve hava kirliliğini görsel kirlilik kaynaklarından biri olarak ele almışlar; görsel kirliliğin (estetik olmayan işlevsiz kullanımlar vb.) çevre kirlenmesine doğrudan katkıda bulunduğunu, birey üzerindeki psikolojik olumsuzlukların yanı sıra toplumsal

Environmental Quality Impacts of Industrial Areas within Residential Areas: Sample of Konya Sugar Factory

Journal of Urban Academy | Volume: ? Issue: ? | ISSN: 2146-9229

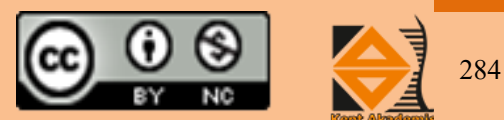


ekonomik kayıplarla sonuçlandığını vurgulamışlar; eski bir tesis olan ve kent yerleşimi içinde kalan Konya Şeker Fabrikası'nın hem görsel hem de çevre açısından oluşturduğu kirlilikten yakın çevresinin önemli ölçüde etkilendiğini ifade etmişlerdir.

\section{Yöntem}

Bu çalışmada Konya kentinde 1954 yllından itibaren şeker üretimi gerçekleştiren, kurulduğu dönemde yerleşimlerden uzak bir konumda yer alan, ancak zamanla kentteki nüfus artışına bağlı kent içi bir sanayi alanına dönüşen Konya Şeker Fabrikası'nın çevresel kalite bağlamında kente ve kentliye etkilerini anlamada ve açıklamada nitel bir araştırma yaklaşımı benimsenmiştir. Makalede Konya Şeker Fabrikası'nın çevresel kaliteye katkılarını değerlendirmede veri toplamada anket tekniğinden yararlanılmıştır. Bu bağlamda fabrika alanına yakınlıkları nedeni ile olası çevresel dışsallıklara ağırlıklı olarak maruz kaldıkları varsayılan konut bölgelerinde mahalle bazlı anket uygulamaları ile yerleşik halkın bilgi, algı ve tutumlarını ölçmek hedeflenmiştir. $\mathrm{Bu}$ değerlendirmede halkın konuya ilişkin nitel değerlendirmeleri istatistiksel analiz ile nicel verilere dönüştürülmüş̧; literatür araştırmasında öngörülemeyen ve anket sorularında yer almayan hususları ortaya koyabilen ve katılımcıların araştırma konusu hakkındaki görüşlerini, bilgi ve tutumlarını kısıtlamaksızın belirtebilmelerini sağlayan açık uçlu anket soruları ile toplanan nitel veriler ankette toplanan nicel verileri ve nitel veriden elde edilen istatistiği desteklemede kullanılmıştır.

\section{1. Çalışma Alanının Genel Özellikleri}

Bir kooperatif girişimi olarak 1954'te kurulan Konya Şeker 40 yıl boyunca kamu tarafından işletilmiştir. Fabrika 1994 yılında özelleştirilerek yönetimi tamamen kooperatiflere devredilmiştir. 2000'li yıllara kadar sadece tek kalem kristal şeker üreten Konya Şeker, 1999'da faaliyet alanlarını genişletmeye başlamıştır (tatlı şerbeti, ilaç şekeri, şekerleme ve çikolata, atıştırmalıklar, et ve süt ürünleri, dondurulmuş ürünler, ayçiçeği yağı, organik gübre, hayvancılık, biyoetanol, elektrik üretimi vb.) ve bazıları dünya ölçeğinde olmak üzere toplam 11 yerleşkede 45 üretim tesisi kurmuştur (Url 3). 200 bin ton/yıl kapasiteli Konya Şeker Fabrikası (Şekil 2) Çumra Şeker Fabrikası ile birlikte Türkiye'nin şeker ihtiyacının \%22'sini karşılamaktadır (Url 4).

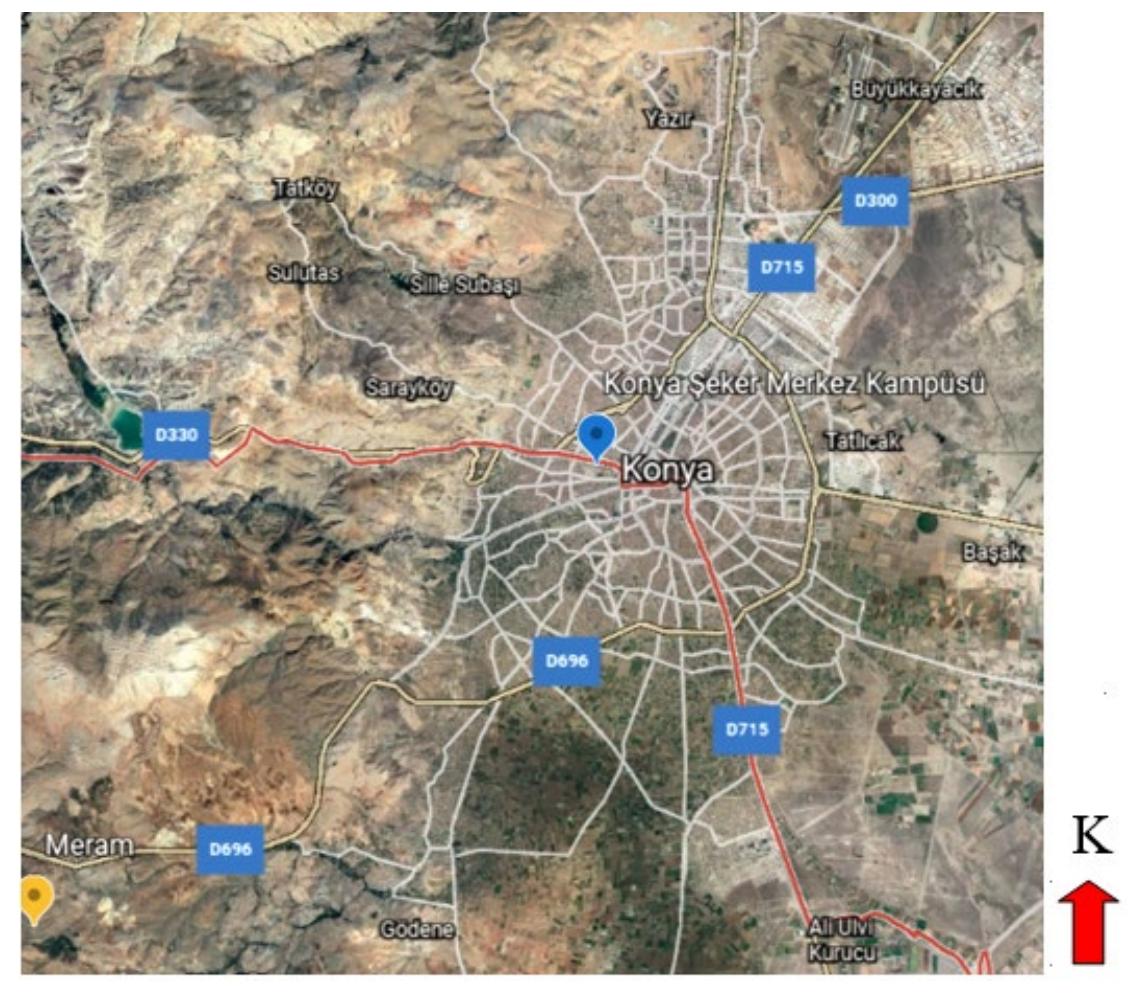

Şekil 2. Fabrika'nın Kent İçindeki ve Meram İlçesi Sınırları İçerisindeki Konumunu Gösterir Google Earth Verisi (Url 5) 
Bu araştırmanın örneklem alanını Konya Şeker tarafından Türk sanayiine kazandırılan 11 yerleşkeden ilki konumundaki (günümüzde Konya Merkez Kampüsü olarak adlandırılan) kampüste 1954 yılından beri faaliyet gösteren (son yıllarda ise Gıda ve Tarım Üniversitesi ve Uydu Destekli Tarım Projesi ile birlikte alanda yer alan) Konya Şeker Fabrikası'nın yakın çevresinde bulunan konut alanları oluşturmaktadır. Konya Şeker Fabrikası alanı $420.628 \mathrm{~m}^{2}$ büyüklüğünde iken kampüste yer alan üniversite ve araştırma alanları yaklaşı $500.000 \mathrm{~m}^{2}$ büyüklüğündedir.

Konya Şeker Fabrikası, Konya kent merkezinin batısında, Beyşehir Caddesi ile Hocafakıh ve Aziz Mahmut Hüdai Caddeleri arasında konumlanmıştır (Şekil 3, Şekil 4). Fabrikanın en önemli yer seçim kriteri batı sınırından geçen demiryolu ağına yakınlı̆̆ı olmuştur. Fabrikanın ilk kurulduğu dönemlerde bölgede yerleşim alanları bulunmamaktadır. Tarihsel süreçte kentte artan nüfusa bağlı fabrika alanı konut bölgeleri ile çevrilmiş, kent içinde kalmıştır. Günümüzde fabrika alanının yakın çevresinde yer alan mahalleler kuzey yönünde Şeker ve Selçuk Mahalleleri, güney yönünde Melikşah ve Alavardı Mahalleleri, doğu yönünde İhsaniye Mahallesi, güneydoğu yönünde Nişantaş Mahallesi, kuzeybatı yönünde ise Hocacihan Mahallesi'dir (Şekil 5).

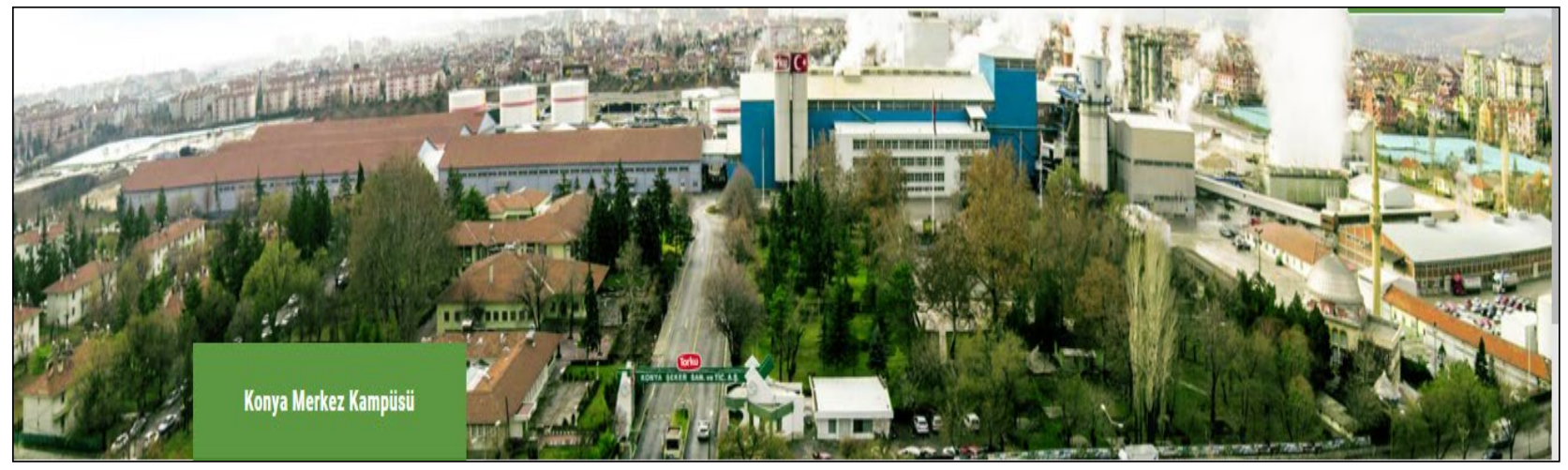

Şekil 3. Konya Şeker Merkez Kampüsü-gündüz görünüm (Url 6)

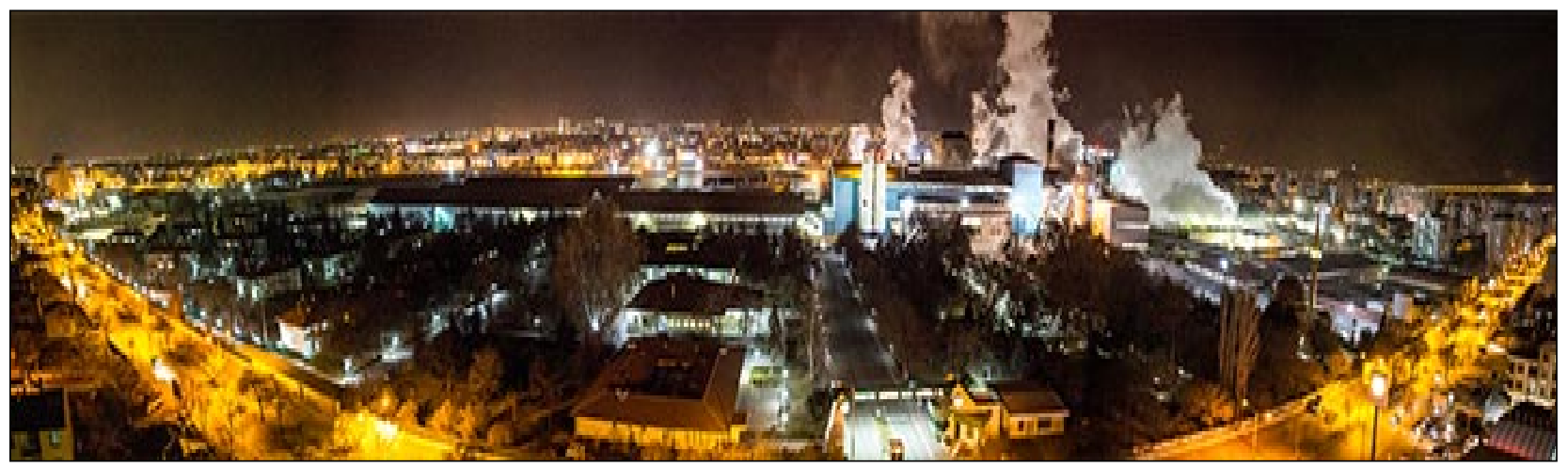

Şekil 4. Konya Şeker Merkez Kampüsü -gece görünüm (Url 6) 


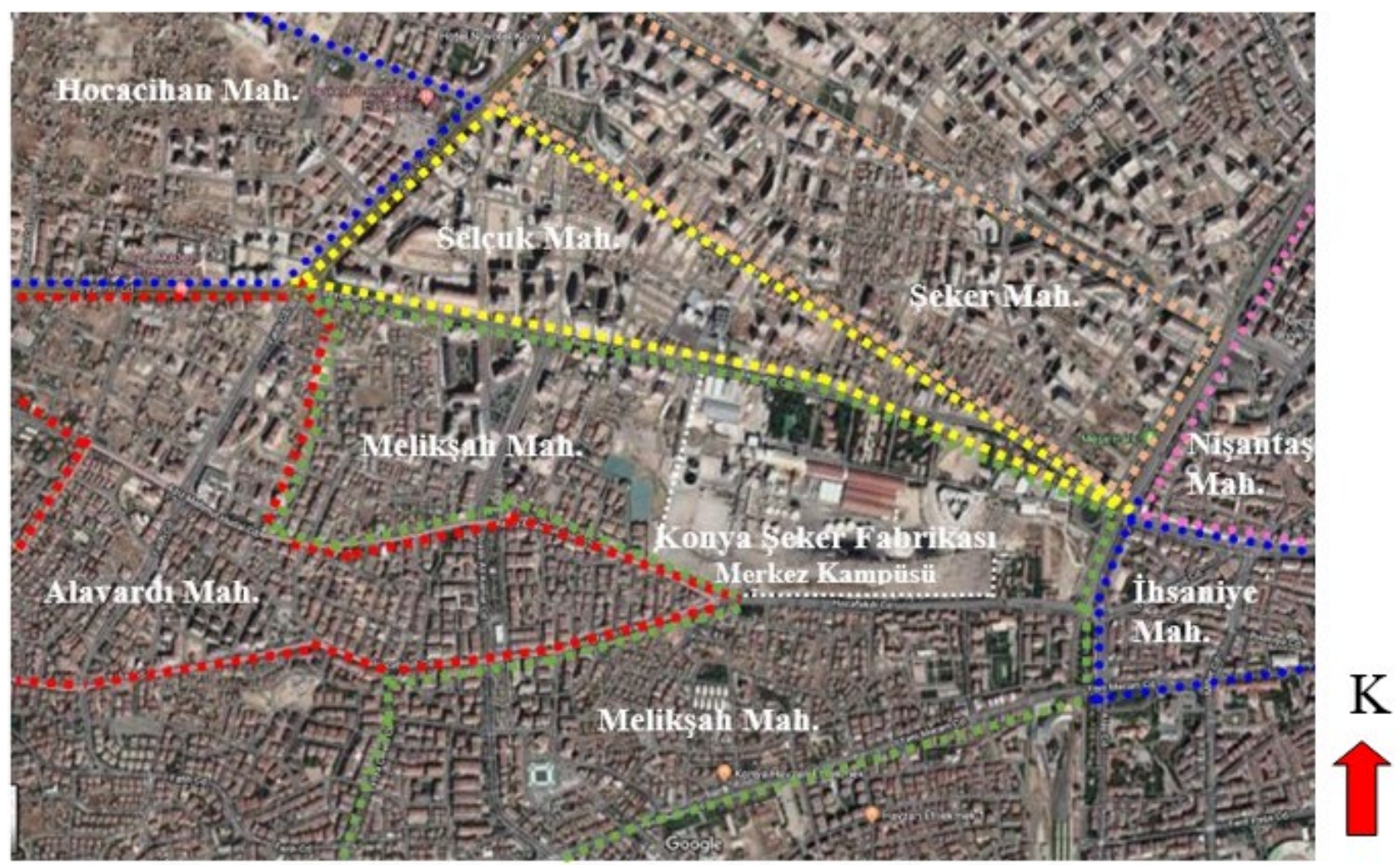

*Yazar tarafindan Google Earth verisi üzerine mahalle sınırları işlenerek hazırlanmıștır.

Şekil 5. Konya Şeker Fabrikası ve yakın çevresinde yer alan örneklem mahalleler

Örneklem alanının oluşturan mahalleler Alavardı, Melikşah, Hocacihan, İhsaniye, Nişantaş, Selçuk ve Şeker Mahalleleri'nden oluşmaktadır. Mahallelerin son 5 yıllık nüfus verileri (Nişantaş mahallesi dışında) mahallelerde nüfusun hızla arttı̆̆ını göstermektedir (Tablo 1).

Tablo 1. Örneklem alanında yer alan mahallelerde nüfus gelişimi (2014-2019)

\begin{tabular}{|c|c|c|c|c|c|c|c|c|}
\hline \multirow{2}{*}{ İlçe: } & \multirow{2}{*}{\multicolumn{2}{|c|}{ Mahalleler: }} & \multicolumn{6}{|c|}{ Yıllara Göre Mahalle Nüfusları: } \\
\hline & & & \multirow{2}{*}{\begin{tabular}{|c|}
$\mathbf{2 0 1 4}$ \\
11.469 \\
\end{tabular}} & \multirow{2}{*}{\begin{tabular}{|c|}
$\mathbf{2 0 1 5}$ \\
11.524
\end{tabular}} & \multirow{2}{*}{\begin{tabular}{|c|}
$\mathbf{2 0 1 6}$ \\
11.738 \\
\end{tabular}} & \multirow{2}{*}{$\begin{array}{c}\mathbf{2 0 1 7} \\
11.881\end{array}$} & \multirow{2}{*}{$\begin{array}{c}\mathbf{2 0 1 8} \\
17.724\end{array}$} & \multirow{2}{*}{$\begin{array}{r}\mathbf{2 0 1 9} \\
18.244 \\
\end{array}$} \\
\hline \multirow{5}{*}{ Meram } & \multirow{2}{*}{ Alavard1 Mah.* } & Alavardı Mah. & & & & & & \\
\hline & & (Eski) Süleymanşah Mah. & 3.282 & 3.127 & 2.939 & $*$ & $*$ & $*$ \\
\hline & \multirow{3}{*}{ Melikşah Mah.** } & (Eski) Armağan Mah. & 3.820 & 3.776 & 3.548 & 3.502 & $* *$ & $* *$ \\
\hline & & (Eski) Dedekorkut Mah. & 6.458 & 7.069 & 7.246 & 7.727 & $* *$ & $* *$ \\
\hline & & Melikşah Mah. & 7.736 & 7.697 & 7.769 & 7.653 & 13.235 & 13.254 \\
\hline \multirow{5}{*}{ Selçuklu } & \multicolumn{2}{|l|}{ Hocacihan Mah. } & 13.186 & 13.463 & 14.093 & 14.303 & 14.448 & 14.831 \\
\hline & \multicolumn{2}{|l|}{ İhsaniye Mah. } & 10.324 & 10.449 & 10.038 & 9.674 & 9.320 & 8.912 \\
\hline & \multicolumn{2}{|l|}{ Nişantaş Mah. } & 12.925 & 12.750 & 12.662 & 12.618 & 12.222 & 11.937 \\
\hline & \multirow{2}{*}{\multicolumn{2}{|c|}{ Selçuk Mah. }} & 5.791 & 5.358 & 5.184 & 5.844 & 6.743 & 7.748 \\
\hline & & Şeker Mah. & 8.800 & 8.814 & 9.264 & 11.180 & 12.839 & 15.441 \\
\hline
\end{tabular}

*, ** Mahalle sınırlarındaki değişimlere bağlı başka bir mahalleye dahil edilen nüfuslar

*** TUIK, 2020, ADNKS Belediye, Köy ve Mahalle Nüfusları (2014-1019) https://biruni.tuik.gov.tr

Environmental Quality Impacts of Industrial Areas within Residential Areas: Sample of Konya Sugar Factory

Journal of Urban Academy | Volume: ? Issue: ? I ISSN: 2146-9229

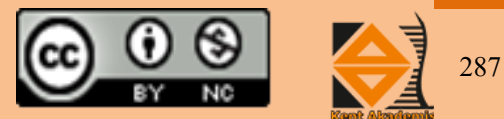




\subsection{Anket Çalışmasının İçeriği}

Alavardı, Melikşah, Hocacihan, İhsaniye, Nişantaş, Selçuk ve Şeker Mahalleleri'nden oluşan örneklem alanının 2019 yılı nüfusu 90.367 olup \%95 güven aralığında bu nüfus büyüklügü için uygun örneklem büyüklüğü 383 'tür (Url 7). Bu çerçevede her bir mahallede nüfusları ile orantılı olmak kaydıyla en az 383 anket hedeflenmiş; 2019 yılında fabrikanın üretimde olduğu Kasım ve Aralık aylarında 529 anket uygulaması gerçekleştirilmiştir (Tablo 2). Katılımcılar arasında 15 yıldan fazla süredir mahallede yaşayanlar çoğunluktadır (\%40).

Tablo 2. Örneklem alanına ilişkin nüfus bilgisi ve örneklem büyüklükleri

\begin{tabular}{|c|c|c|c|c|c|}
\hline \multirow{2}{*}{ Mahalleler: } & \multirow{2}{*}{ Nüfus [2019] } & \multirow{2}{*}{ \% } & \multicolumn{2}{|c|}{ Anket sayısı } & \multirow{2}{*}{ (\%) } \\
\cline { 4 - 5 } & & & Hedeflenen & Gerçekleşen & \\
\hline Alavardı Mah. & 18.244 & 20,2 & 77 & 91 & 17,2 \\
\hline Melikşah Mah. & 13.254 & 14,7 & 56 & 101 & 19,1 \\
\hline Hocacihan Mah. & 14.831 & 16,4 & 63 & 58 & 11,0 \\
\hline İhsaniye Mah. & 8.912 & 9,9 & 38 & 72 & 13,6 \\
\hline Nişantaş Mah. & 11.937 & 13,2 & 51 & 75 & 14,2 \\
\hline Selçuk Mah. & 7.748 & 8,6 & 33 & 32 & 6,0 \\
\hline Şeker Mah. & 15.441 & 17,1 & 65 & 100 & 18,9 \\
\hline Toplam: & $\mathbf{9 0 . 3 6 7}$ & $\mathbf{1 0 0 , 0}$ & $\mathbf{3 8 3}$ & $\mathbf{5 2 9}$ & $\mathbf{1 0 0 , 0}$ \\
\hline
\end{tabular}

Katılımcıların \%56,3'ü kendi evinde, $\% 42,3$ 'ü kirada, \%1,3’ü ise lojmanda yaşamaktadır. Anketler fabrika alanına maksimum $500 \mathrm{~m}$. mesafede oturan halka $\% 28,2$ düzeyinde, 501-1000 $\mathrm{m}$. mesafede oturanlara ise $\% 21,7$ düzeyinde uygulanmıştır (Tablo 3).

Tablo 3. Oturulan evin Konya Şeker Fabrikası'na uzaklı̆̆g

\begin{tabular}{|c|c|c|c|c|c|c|}
\hline & $\mathbf{5 0 0} \mathbf{~ m}$. den daha yakın & $\mathbf{5 0 1 - 1 0 0 0 ~} \mathbf{m}$ & $\mathbf{1 0 0 1 - 1 5 0 0} \mathbf{~ m}$ & $\mathbf{1 5 0 1} \mathbf{~ m - 2 0 0 0} \mathbf{~ m}$ & $\mathbf{2 0 0 1} \mathbf{~ m . d e n ~ f a z l a ~}$ & Toplam \\
\hline Frekans & 149 & 115 & 95 & 86 & 84 & $\mathbf{5 2 9}$ \\
\hline $\mathbf{\%}$ & 28,2 & 21,7 & 18,0 & 16,3 & 15,9 & $\mathbf{1 0 0 , 1}$ \\
\hline
\end{tabular}

Anket soruları katılımcıların demografik özellikleri, fabrikadan kaynaklı hava, gürültü, çevre ve görüntü kirliliği vb. olumsuzluklar, geçmişe göre çevresel kalite değerlendirmesi, fabrika alanının kent dışına taşınmasına yönelik görüşler ve fabrikanın taşınması halinde âtıl kalacak alana verilebilecek fonksiyon önerileri eksenlerinde kategorize edilmiştir.

\section{Bulgular}

\subsection{Katılımcı Özellikleri}

Saha çalışması kapsamında Konya Şeker Fabrikası'nın yakınında ve sınır komşuluğunda bulunan Alavardı, Melikşah, Hocacihan, İhsaniye, Nişantaş, Selçuk ve Şeker Mahalleleri'nde 2019 y1lı Kasım ayında toplam 529 anket uygulanmıştır. Ankete 208 kadın $(\% 39,3), 321(\% 60,7)$ erkek katılmış olup 16-25 yaş grubu $(\% 29,7)$ ve 26-25 yaş grubu $(\% 23,8)$ ağırlıklıdır (Şekil 6). Öğrenim durumları ise ağırlıklı olarak lise $(\% 30,2)$ ve üniversitedir $(\% 29,3)$ (Şekil 7). 


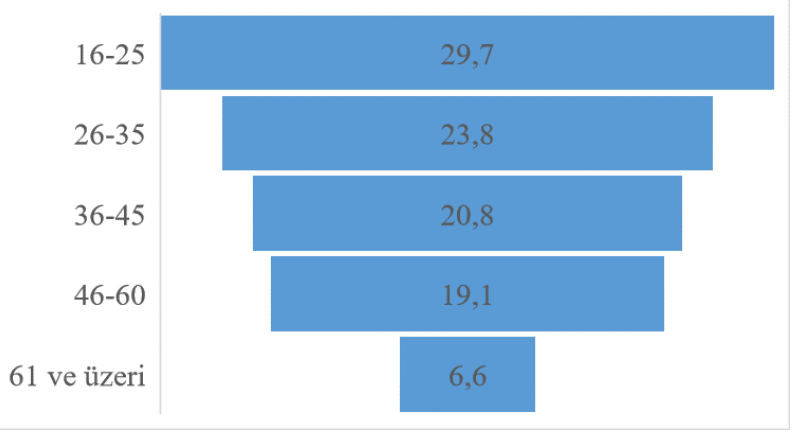

Şekil 6. Katılımcıların yaş grupları

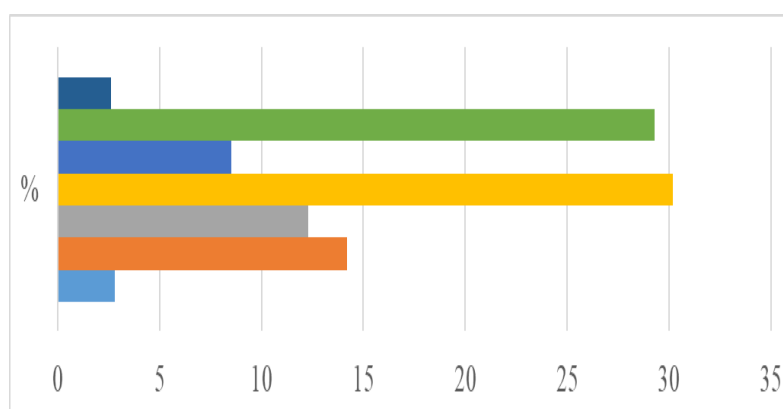

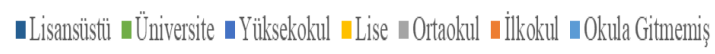

Şekil 7. Katılımcıların öğrenim durumu

Meslek grupları dağılımında (Şekil 8) ev hanımı $(\% 17,4)$, işsizler $(\% 17,6)$ ve esnaflar $(\% 15,1)$ ağırlıklıdır. Genç nüfusun yoğunluğu işsizlik oranını alanda yükseltmiştir. Katılımcıların \%77,5'si Konyalıdır. Konyalı olmayanlar arasında ise Ankaralılar $(\% 3,9)$ ve Karamanlılar $(\% 1,9)$ çoğunluktadır.

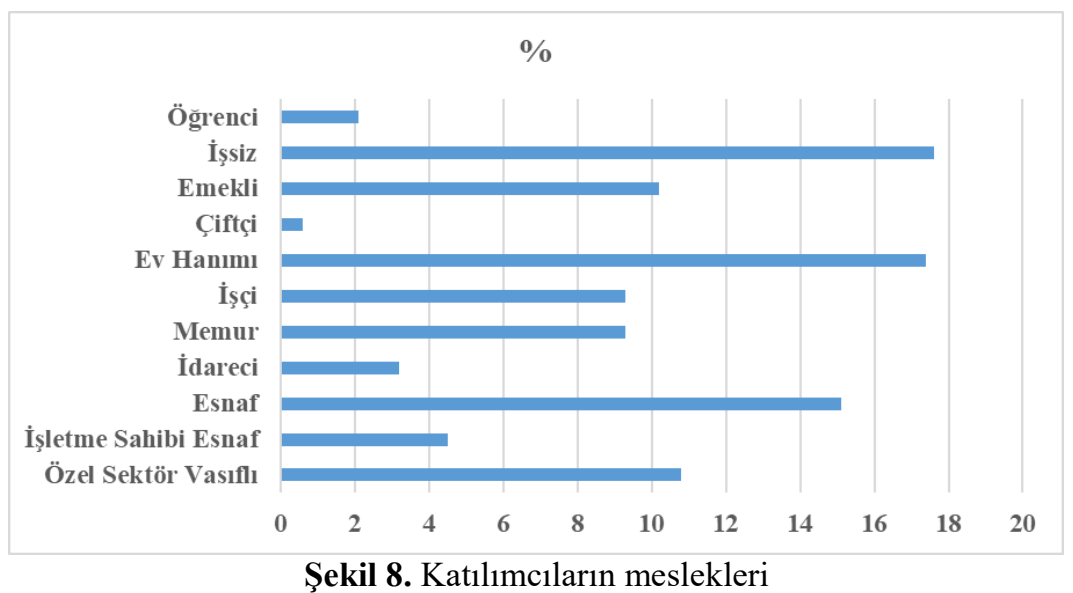

Katılımcılar arasında 15 yıldan fazla bir süredir alanda yaşayanlar $(\% 35,2)$ çoğunluktadır. 1-5 yıldır alanda yaşayanlar $(\% 26,7)$ ve 6-10 yıldır alanda yaşayanlar $(\% 23,8)$ da ağırlıklıdır. 15 yılı aşkın süredir mahallede bulunanların yoğun olmasına karşın mahallede yaşamaktan duyulan memnuniyet büyük ölçüde "orta" $(\% 43,7)$ düzeydedir (Şekil 9).

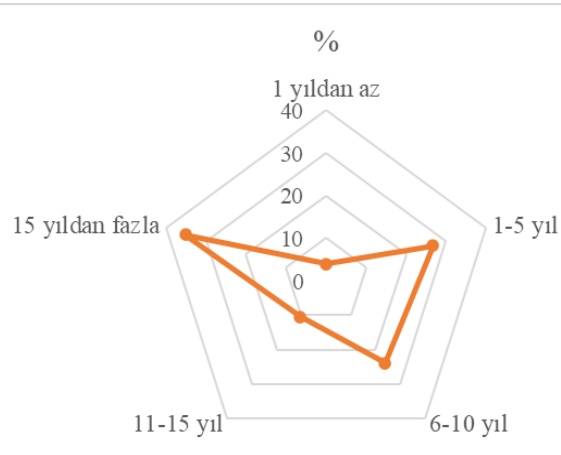

Katılımcıların mahallede bulunma süreleri

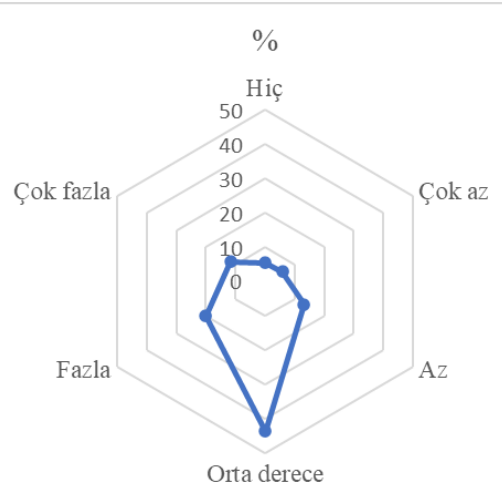

Katılımcıların mahalle memnuniyetleri

Şekil 9. Katılımcıların mahallede bulunma süreleri ve mahalle memnuniyetleri 
Mahallede bulunmalarına ilişkin katılımcılar büyük ölçüde; “İşyerine yakınlık” (\%20,1), "Ailenin yanında olma" $(\% 18,5)$, "Ev sahibi olma” (\%15,8), “İşyerinin bulunması” (\%10,3), “Okula yakınlık” (\%9,8), "Doğma büyüme alanda bulunma" (\%7,1), "Bölgeyi sevme" (\%5,8), "Merkezi konum, ulaşım kolaylığı”" $(\% 5,1)$, "Nezih, huzurlu, sakin oluşu” $(\% 2,9)$, "Aile bireylerinin işyerine yakınlık" $(\% 2,5)$, ve "Zorunluluk" $(\% 2,0)$ gerekçelerini belirtmişlerdir. Bunun yanı sıra düşük oranlarda "Komşuluk ilişkileri”, "Arkadaş çevresi”, "Olanakların fazlalığı", "Yaşam koşullarının elverişliliği”, "Akrabalara yakın olma", "Fabrikada çalışma" ve "Yurdun bulunması” gerekçeleri de katılımcılarca ifade edilmiştir.

\section{2. Şeker Fabrikasının Önemi ile Kente ve Kentliye Olan Etkilerinin Değerlendirilmesi}

"Fabrika sizin için neyi ifade ediyor?" sorusu bağlamında katılımcılar fabrikayı \%34,4 düzeyinde "Konya kentinin ekonomisindeki en önemli fabrika", \%33,2 düzeyinde "iş alanı” ve \%13,3 düzeyinde "Konya’nın tanıtımını yapan bir kuruluş” olarak nitelemişlerdir. Ayrıca katılımcıların \%8,2'si fabrikanın faydasından çok “koku, hava kirliliği, gürültü, duman, sağlığı olumsuz etkileme, çevre kirliliği, trafik ve yer işgal etme vb.” zararı olduğu düşüncesindedir.

Halk fabrikanın katkılarından şeker \%76,7, çikolata \%33,8 ve bisküvi \%25,7 ile süt ürünleri, üniversite, et ürünleri, yăg, çok yönlü gıda üretimi ve ambalaj üretimi vb. alanlarındaki diğer faaliyetlerinden \%1,7 düzeyinde bilgi sahibidir. Fakat katılımcıların \%10,2'si bu konuda herhangi bir fikir belirtmemişlerdir. Katılımcılar fabrikanın yaptığı ve/veya katkıda bulunduğu ekonomik faaliyetlerden \%55- \%89 düzeyinde memnundurlar (Şeker: \%89,6, Çikolata: \%71,5, Bisküvi $\% 55,0)$.

Katılımcılar şeker fabrikasının yakın çevresindeki hava kalitesini \%42,3 düzeyinde "Kötü”, \%19,1 düzeyinde “Çok kötü” olarak değerlendirmektedirler. "Orta" düzey değerlendirmesinde bulunanlar \%24,2 iken iyi ve çok iyi değerlendirmesinde bulunanlar sadece \%8,5 düzeyindedir. Katılımcıların şeker fabrikasının yakın çevresindeki hava kalitesine yönelik değerlendirmeleri alanın yakın çevresinde hava kalitesinin çok düşük olduğunu vurgulamaktadır. Katılımcıların eskiye göre şeker fabrikasının yakın çevresindeki hava kalitesine yönelik değerlendirmeleri ise benzer oranlardadir $(\% 22,9-25,5)$ (Tablo 4).

Tablo 4. Katılımcıların şeker fabrikasının yakın çevresindeki hava kalitesine yönelik değerlendirmeleri

\begin{tabular}{|l|c|c|}
\hline $\begin{array}{l}\text { Şeker fabrikasının } \\
\text { yakın çevresindeki } \\
\text { hava kalitesi }\end{array}$ & Sayı & \% \\
\hline Çok kötü & 101 & 19,1 \\
\hline Kötü & 224 & 42,3 \\
\hline Orta & 128 & 24,2 \\
\hline İyi & 31 & 5,9 \\
\hline Çok iyi & 16 & 3,0 \\
\hline Fikri yok & 29 & 5,5 \\
\hline TOPLAM & $\mathbf{5 2 9}$ & $\mathbf{1 0 0 , 0}$ \\
\hline
\end{tabular}

\begin{tabular}{|l|c|c|}
\hline $\begin{array}{l}\text { Eskiye göre şeker fabrikasının } \\
\text { yakın çevresindeki hava kalitesi }\end{array}$ & Sayı & \% \\
\hline Daha iyi & 123 & 23,2 \\
\hline Daha kötü & 121 & 22,9 \\
\hline Aynı, değişmedi & 135 & 25,5 \\
\hline Fikri yok & 150 & 28,4 \\
\hline TOPLAM & $\mathbf{5 2 9}$ & $\mathbf{1 0 0 , 0}$ \\
\hline
\end{tabular}

Şeker fabrikasının yakın çevresindeki hava kalitesinden memnun olmayanlar fabrikadan yayılan şeker pancarının kokusunun özellikle akşam saatlerinde ve fabrikanın üretim yaptığı kış aylarında daha dayanılmaz olduğunu (\%40,6), Ulaşım yoğunluğundan ve fabrikadan kaynaklı düşük hava kalitesi nedeniyle temiz hava alamadıklarını (\%13,3), eskiye oranla alınan önlemlerle azalmakla $(\% 13,0)$ birlikte aşırı buhar/duman salınımının söz konusu olduğunu $(\% 12,4)$ ifade etmişler fabrikanın yanlış yer seçiminden kaynaklı konutlarda gözlenen çevre kirliliği, güvensiz ortam $(\% 4,1)$ ve solunum yolu hastalıkları $(\% 3,2)$ başta olmak üzere sağlık sorunlarına sebebiyet vermesine $(\% 1,3)$ işaret etmişlerdir (Tablo 5).

Şeker Fabrikasından kaynaklı hava kirliliğinin ailelerine olan olumsuz etkilerine ilişkin; pancar, şeker işleme, küspe vb. kaynaklı kötü koku $(\% 28,1)$, düşük hava kalitesi, temiz hava alamama $(\% 12,4)$, nefes alma güçlüğ̈̈, astım vb. solunum yolu rahatsızlıkları $(\% 10,3)$, baş ağrısı, mide ağrısı, boğaz ve burun rahatsızlıkları, solunum sistemi, kanser vb. 
rahatsızlıklar, sık hastalanma vb. sağlık sorunları $(\% 7,9)$ katılımcıların en çok önemsediği sorunlar olarak gösterilmiştir. Bunun yanı sıra evi havalandıramama, çevre kirliliği, trafik yoğunluğu, balkona çıkamama, her türlü hava kirliliği oluşturması, çamaşırları kötü kokutması, görüntü ve gürültü kirliliği vb. mahalle sakinlerinin yaşam kalitesini düşüren olumsuzluklar sıralanmış; ancak bölgedeki kötü kokuya alıştıklarını $(\% 12,6)$ ifade edenler de olmuştur (Tablo 6).

Tablo 5. Şeker fabrikasının yakın çevresindeki hava kalitesine ilişkin değerlendirmeler

\begin{tabular}{|c|c|c|c|c|c|}
\hline Değerlendirme & Sayı & $\%$ & Değerlendirme & \multicolumn{2}{|c|}{ Sayı $\%$} \\
\hline Üretim zamanı kötü koku (pancar, şeker işleme, küspe vb.) & 128 & 40,6 & Görüntü kirliliği & 4 & 1,3 \\
\hline $\begin{array}{l}\text { Ulaşım yoğunluğundan ve fabrikadan kaynaklı düşük hava kalitesi, } \\
\text { temiz hava alamama }\end{array}$ & 42 & 13,3 & $\begin{array}{l}\text { Sağlik sorunlarına sebebiyet } \\
\text { verme }\end{array}$ & 4 & 1,3 \\
\hline Aşırı buhar/duman salınımı, kent havasını olumsuz etkileme & 39 & 12,4 & $\begin{array}{l}\text { Yaz dönemlerinde çok iyi, } \\
\text { kişın çok kötü }\end{array}$ & 3 & 1,0 \\
\hline $\begin{array}{l}\text { Fabrikanın yanlış yer seçiminden kaynaklı konutlarda gözlenen } \\
\text { sorunlar (çevre kirliliği, güvensiz ortam vb.) }\end{array}$ & 13 & 4,1 & Çamaşırlara sinen kötü koku & 2 & 0,6 \\
\hline Nefes alma güçlüğü, astım vb. solunum yolu rahatsızlıkları & 10 & 3,2 & $\begin{array}{l}\text { Trafik yoğunluğuna sebebiyet } \\
\text { vermesi }\end{array}$ & 2 & 0,6 \\
\hline Çevre kirliliği (is oluşumu, sevk kamyonları vb.) & 8 & 2,5 & $\begin{array}{l}\text { Alınan tedbirlerle rahatsiz } \\
\text { olmama }\end{array}$ & 41 & 13,0 \\
\hline Gürültü kirliliği & 7 & 2,2 & Fikri yok & 7 & 2,2 \\
\hline Evi havalandıramama & 5 & 1,6 & Toplam: & 315 & 100,0 \\
\hline
\end{tabular}

* Açık uçlu sorulara verilen yanıtların frekans dağılımları yapılmıştır.

Tablo 6. Şeker Fabrikasından kaynaklı hava kirliliğinin bireylere ve ailelerine olumsuz etkilerine ilişkin değerlendirmeler

\begin{tabular}{|c|c|c|c|c|c|}
\hline Değerlendirme & Sayı & $\%$ & Değerlendirme & Sayı & $\%$ \\
\hline Kötü koku (pancar, şeker işleme, küspe vb.) & 156 & 28,1 & Görüntü kirliliği & 11 & 2,0 \\
\hline Düşük hava kalitesi, temiz hava alamama & 69 & 12,4 & Gürültü kirliliği & 11 & 2,0 \\
\hline Nefes alma güçlüğü, astım vb. solunum yolu rahatsızlıkları & 57 & 10,3 & $\begin{array}{l}\text { Bölgeden geçerken dahi } \\
\text { rahatsı olma }\end{array}$ & 6 & 1,1 \\
\hline $\begin{array}{l}\text { Sağlık sorunları (baş ağrısı, mide ağrısı, boğaz ve burun } \\
\text { rahatsılıkları, solunum sistemi, kanser vb. rahatsızlıklar, sık } \\
\text { hastalanma) }\end{array}$ & 44 & 7,9 & Doğal çevreye zarar & 6 & 1,1 \\
\hline Evi havalandiramama & 20 & 3,6 & $\begin{array}{l}\text { Sis vb. olumsuz hava } \\
\text { koşulları }\end{array}$ & 5 & 0,9 \\
\hline Çevre kirliliği (is oluşumu, sevk kamyonları vb.) & 17 & 3,1 & Düşük yaşam kalitesi & 4 & 0,7 \\
\hline Duman & 16 & 2,9 & $\begin{array}{l}\text { Çocukların bağışıklık sistemi } \\
\text { sorunlarını artırma }\end{array}$ & 4 & 0,7 \\
\hline Trafik yoğunluğuna sebebiyet vermesi & 15 & 2,7 & Zehirlenme korkusu & 3 & 0,5 \\
\hline Balkon vb. dışarıda vakit geçirememe & 14 & 2,5 & $\begin{array}{l}\text { Alınan tedbirlerle rahatsız } \\
\text { olmama }\end{array}$ & 70 & 12,6 \\
\hline Çamaşırlara sinen kötü koku & 11 & 2,0 & Fikri yok & 17 & 3,1 \\
\hline Toplam & \multicolumn{3}{|c|}{\begin{tabular}{|l|l|l|l|}
556 & 100,0 & Toplam
\end{tabular}} & \multicolumn{2}{|c|}{\begin{tabular}{|l|l|l}
556 & 100,0
\end{tabular}} \\
\hline
\end{tabular}

* Açık uçlu sorulara verilen yanıtların frekans dağılımları yapılmıştır. Katılımcılar birden fazla değerlendirmede bulunabilmişlerdir.

Şeker fabrikasının yakın çevresinde fabrikadan kaynaklı gürültü katılımcıların \%67'si tarafından büyük bir sorun olarak görülmemektedir. Ancak \%20,8 düzeyinde fabrika bölgesinde gürültü büyük bir sorun olarak ifade edilmiştir. Fabrikaya pancar getiren ağır tonajlı araçların yoğunluğuna bağlı artan trafik, pancar dökümü esnasındaki ses ve makinelerin sesi başlıca gürültü kaynakları olarak ifade edilirken, gürültünün özellikle fabrikaya yakın konutlarda daha çok hissedildiği tespit edilmiştir (Tablo 7).

Tablo 7. Şeker fabrikasının yakın çevresinde fabrikadan kaynaklı gürültü kirliliğine yönelik değerlendirmeler 


\begin{tabular}{|l|c|c|}
\hline Gürültü sorunu düzeyi & Sayı & \% \\
\hline Çok az & 95 & 18,0 \\
\hline Az & 127 & 24,0 \\
\hline Orta & 132 & 25,0 \\
\hline Fazlaca & 74 & 14,0 \\
\hline Çok fazla & 36 & 6,8 \\
\hline Fikri yok & 65 & 12,3 \\
\hline TOPLAM & 529 & 100,0 \\
\hline
\end{tabular}

\begin{tabular}{|l|}
\hline Gerekçeler \\
\hline - Fabrikaya pancar getiren ağır tonajlı \\
araçların yoğunluğuna bağlı artan trafiğin \\
gürültüsü \\
- Fabrikadaki pancar dökümü esnasında \\
oluşan ses \\
- Fabrikada üretim esnasında makinelerin sesi
\end{tabular}

Katılımcıların \%29,1'i şeker fabrikasının yakın çevresinde fabrikadan kaynaklı çevre kirliliğinin fazla olduğu düşüncesindedir. Ayrıca çevre kirliliğine ilişkin \%26,5 düzeyinde "orta" düzey değerlendirmesinde bulunulmuştur. Başlıca çevresel kirlilik faktörleri rüzgârla artan kötü koku, buhar/duman ve is oluşumu, pancar getiren araçların çevreye bıraktığı çamurlar ve artan atık miktarına bağlı çevresel kirlilik olarak değerlendirilmiştir. Katılımcıların \%29,7'si ise alınan tedbirlerle bölgede çevresel kirliliğin olmadığı düşüncesindedir (Tablo 8). Katılımcıların çoğunluğu $(\% 62,8)$ tarafindan Şeker Fabrikasından kaynaklı koku baş edilmesi gereken büyük bir sorun olarak değerlendirilirken; katılımcıların \%18,3'i tarafından ise orta dereceli bir sorun olarak görülmüştür. Katılımcıların sadece \%12,5'i fabrika kaynaklı kokunun az sorun teşkil ettiğini belirtmiştir.

Elde edilen bulgular, yaşam kalitesini azaltan başlıca faktörler olarak literatürde Atkins ve ark., 2015; Li ve ark., 2016; Salihoğlu, 2016 ile Silva \& Mendes, 2012 tarafindan vurgulanan "kentsel hava kirliliği ve kentsel gürülttü" sorunlarının; Leby \& Hashim, 2010; Lowe ve ark., 2013; Parkinson ve ark., 2006; Salihoğlu, 2016, Tapsuwan ve ark., 2018 ile Yeang, 2006 tarafindan vurgulanan "çevresel kirlenme"nin alanda baskın olduğunu göstermiştir.

Tablo 8. Şeker fabrikasının yakın çevresinde fabrikadan kaynaklı çevre kirliliğine yönelik değerlendirmeler

\begin{tabular}{|l|c|c|}
\hline Çevre kirliliği düzeyi & Sayı & \% \\
\hline Çok az & 51 & 9,7 \\
\hline Az & 106 & 20,0 \\
\hline Orta & 140 & 26,5 \\
\hline Fazlaca & 97 & 18,3 \\
\hline Çok fazla & 57 & 10,8 \\
\hline Fikri yok & 78 & 14,7 \\
\hline TOPLAM & 529 & 100,0 \\
\hline
\end{tabular}

\begin{tabular}{|l|}
\hline Gerekçeler \\
\hline \\
- Rüzgârla artan kötü koku \\
- Buhar/duman ve is oluşumu \\
- Pancar getiren araçların çevreye bıraktığı \\
çamurlar \\
-Yaşam alanlarını kirletme (artan atıklar) \\
\end{tabular}

Katılımcıların \%44,8'i tarafından şeker fabrikasının bulunduğu bölgeyi güvensiz yapmadığı ifade edilirken katılımcıların \%28,7'si fabrikanın bulunduğu bölgeyi "ağır vasıtalar ile diğer araçlardan kaynaklı trafiğin yoğunluğu”, "fazlaca alan kaplaması", "sağlı̆̆ı yitirme endişesi”" ve “çevredeki insan çeşitliliği”" gerekçeleri ile güvensiz yaptığını dile getirmiştir.

Tek örneklem t testi ile yapılan analizlere ${ }^{2}$ göre katılımcılar fabrika alanının içinde yer alan ağaçların çevreyi güzelleştirdiğini [t: +; ortalama 3,18; p:0,001], fabrikanın bulunduğu bölgeye değer kattığını [t: +; ortalama 3,33; p:0]; fakat fabrikanın alanda aşırı trafik yoğunluğu [t: + ; ortalama 3,18; p:0] ile çeşitli çevre sorunlarına sebep olduğunu [t: + ; ortalama 3,$63 ; p: 0]$ ve Konya halkının sağlığının fabrikanın çevre önlemleri almasına bağlı olduğunu [t: +; ortalama 3,3; p:0] vurgulamışlardır. Fabrikanın çevresel kalite bağlamında yol açtığı sorunları ifade eden katılımcıların yanı sıra fabrikanın çevreyi korumak adına gereken önlemleri aldığını düşünen katılımcılar da [t: +; ortalama 3,3; p:0] bulunmaktadir.

${ }^{2}$ Tek örneklem $t$ testi analizi bağlamında; $t$ değerinin işareti + ise ve $\alpha<0,05$ ise; yargıya "katılma" söz konusudur. $t$ değerinin işareti - ise ve $\alpha<0,05$ ise; yargıya "katılmama" söz konusudur. $t$ değerinin işareti ne olursa olsun, $\alpha>0,05$ ise; deneğin yargı ile ilgili "fikri yok" tur. 
Pek çok insana iş imkânı sağlamasına karşın şeker fabrikasının çevreye olan olumsuz etkileri nedeniyle şehir dışına çıkarılması [t: +; ortalama 3,63; p:0] katılımcılar tarafından gerekli görülmektedir. Fabrikanın Konya halkının yaşam kalitesini azalttığı görüşünde ise kararsız olan katılımcılar [t: +; ortalama 3,03; p:0,617] fabrikanın alanının kaldırılmasıyla evlerinin ve bulunduğu bölgenin daha da değer kazanacağını [t: +; ortalama 3,11; p:0,042], kiraların ve ev fiyatlarının artacağını [t: +; ortalama 3,13; $p: 0,016]$, bu çevrede oturmak isteyenlerin azalmayacağını [t: -; ortalama 2,49; p:0] düşünmektedir.

Katılımcılar fabrikanın şehir dışına çıkarılması halinde âtıl kalacak alana yönelik öneri alan kullanımları çevresel kaliteye katkı bağlamında olumlu alan kullanımlarında (rekreasyon, spor alanı, sosyo-kültürel alan vb.) ve düşük yapı yoğunluğu gerektiren üniversite, festival ve fuar alanı vb. fonksiyonlarda yoğunlaşmışlardır. Ancak açık-yeşil alan kullanımı düşük olan alışveriş merkezi kullanımını hava kirliliğine sebebiyet vermeme ve çevre kalitesini arttırma noktasında destekleyen katılımcılar da mevcuttur. Kongre merkezi, sinema, tiyatro vb. sosyo-kültürel alan [t: + ; ortalama 3,$72 ; p: 0]$, üniversite alanı $[t:+$; ortalama 3,$3 ; p: 0]$ ve festival /fuar alanına $[t$ : + ; ortalama 3,56 ; p:0] dönüştürülmesi, duvarlarının kaldırılarak büyük bir park (spor, piknik, oyun alanı vb.) olarak düzenlenmesi ( $t$ : + ; ortalama 3,$86 ; p: 0]$, alanın ağaçlandırılarak kent havasının temizlenmesini sağlaması [t: +; ortalama 4,16; p:0] yönündeki görüşler desteklenmiştir. Alanda yüksek katlı konutların yapılması görüşü [t: -; ortalama 2,21; p:0] katılımcılar tarafından desteklenmez iken, çoğunlukla yatay düzlemde yapılaşmış alan yoğunluğu fazla olan alışveriş merkezi [t: +; ortalama 3,14; p:0,017] kullanımları hava kirliliği açısından daha az kirletici görülmüştür.

\subsection{Mahalle Bazlı Araştırma Bulguları}

Şeker fabrikasının yakın çevresindeki hava kalitesinin [mevcut durumu ve eskiye kıyasla durumu açısından] katılımcıların oturdukları mahallelere göre değiştiği varsayılmıştır. Ayrıca gürültü, koku vb. diğer kirlilik türleri ile bulunulan mahalleden memnun olma durumu vb. pek çok değişkenin mahalle kriteri ile ilgili olup olmadıkları araştırılmıştır. Bu ilişki durumlarını ölçmek için; "mahalle" değişkeni belirtilen değişkenler ile çaprazlanmış (Crosstabulation) ve Ki-kare Testi (Chi-square Test) ${ }^{3}$ uygulanmıştır.

Bulgular şeker fabrikasının yakın çevresindeki hava kalitesinin [mevcut durumu ve eskiye göre değişim açısından] katılımcıların oturdukları mahallelere göre değişim gösterdiğini doğrulamıştır $\left[x^{2}=50,607, d f=30, p=0,011 \leq 0,05\right]$. Şeker, Hocacihan, Melikşah, Selçuk ve Nişantaş Mahalleleri hava kirliliğinin daha çok olduğu mahalleler olur iken, örneklem mahallelerinde eskiye göre hava kalitesi değişimleri istatistiksel anlamda farklılık göstermemektedir.

"Mahalle" değişkeni bulunulan "mahallede yaşamaktan memnun olma düzeyi” ve "çevre kirliliği” değişkenlerine bağlı değildir. Ancak bulgular fabrika çevresinde gözlenen gürültü $\left[x^{2}=48,230, d f=30, p=0,019 \leq 0,05\right]$, koku sorunu $\left[x^{2}=45,652, d f=30, p=0,034 \leq 0,05\right]$, trafik yoğunluğu $\left[x^{2}=51,832, d f=30, p=0,008 \leq 0,05\right]$, yaşam kalitesini azaltma $\left[x^{2}=42,891, d f=24, p=0,010 \leq 0,05\right]$, bölgeyi güvensiz yapma $\left[x^{2}=42,891, d f=24, p=0,010 \leq 0,05\right]$ sorunlarının mahalle değişkeni ile doğrudan ilişkili olduklarını göstermiştir: Şeker fabrikasının yakın çevresinde fabrikadan kaynaklı gürültü sorununun bulunma durumu fabrikanın güney ve batı sınırında yer alan Melikşah mahallesinde çok fazla iken fabrika alanına en uzak örneklem alanı durumundaki Hocacihan mahallesinde ise en az düzeydedir. Katılımcıların birincil önemli çevre sorunu niteliğindeki kötü koku sorunu (sırasıyla) Melikşah, Şeker, Selçuk ve Alavardı mahallelerinde yaşayan katılımcılar tarafından daha çok dile getirilmiştir. Bu mahallelerden Melikşah ve Alavardı mahallelerinde yaşayanlar fabrika alanına yakınlıklarının yanı sıra Konya'da hâkim rüzgâr yönünün kuzeyli rüzgârlar olması nedeniyle meteorolojik faktörlere bağlı olarak da kötü koku sorununu daha çok hissetmektedir. Fabrikanın sınır komşuluğundaki

\footnotetext{
${ }^{3}$ Ki-kare testi (chi-square test: $x^{2}$ ) deneysel olarak elde edilen sonuçları, bazı hipotezlerde teorik olarak beklenenlerle karşılaştırmada kullanılan yararlı bir yöntemdir. Dolayısıyla Ki-kare, gözlemlenen ve beklenen frekansların gerçek sapmalarının bir ölçüsüdür (Url 8). Test frekans dağılımları üzerinden işlem yapar ve serbestlik derecesi (df) ile karakterize edilir. Değişkenler arası ilgiler ölçülürken $\mathrm{x}^{2}$, iki özelliğin birbirinden bağımsız olduğu varsayımıyla $\left(\mathrm{H}_{0}\right.$ : sıfır hipotezi) hesaplanır. Ki-kare testinde hesaplanacak değer, ki-kare değeri değil olasılık değeri olan p (Asymp. Sig.)'dir. $\mathrm{p} \leq 0,05$ ise $\mathrm{H}_{0}$ hipotezi reddedilir (iki faktör arası ilişki vardır); $\mathrm{p}>0,05$ ise $\mathrm{H}_{0}$ hipotezi kabul edilir (iki faktör arası ilişki yoktur) (Url 9).
} 
Melikşah ve Selçuk mahallelerinde fabrikanın ulaşım bağlantılarının yer aldığı yollarda daha çok ulaşım sorununa sebep olduğu düşünülmektedir. "Fabrikanın bulunduğu çevreyi güvensiz yaptığı" görüşü fabrikanın sınır komşuluğundaki Melikşah ve Selçuk mahallelerinde daha çok ifade edilirken, güvenlik konusunda fabrikadan en memnun olan katılımcılar diğer mahallelere kıyasla fabrika alanına daha uzaktaki Hocacihan mahallesinde ikamet etmektedirler. Gürültü, kötü koku, güvenlik ve ulaşım sorunu vb. sorunlardan daha çok yakınan fabrika alanı komşuluğundaki Melikşah ve Selçuk mahalleleri sakinleri, benzer şekilde "fabrikanın yaşam kalitesini azaltan bir olgu olduğunu” da çoğunlukla vurgulayan katılımcılardır.

"Fabrikanın bulunduğu bölgeye değer katma" $\left[x^{2}=36,218, d f=24, p=0,052 \leq 0,05\right]$, "içerdiği ağaç varlığ ile çevreyi güzelleştirme" $\left[x^{2}=60,778, d f=30, p=0,001 \leq 0,05\right] \mathrm{vb}$. katkılarının öznel değerlendirmeleri ise "mahalle" değişkenine bağlı değişim göstermektedir: "Fabrikanın bulunduğu bölgeye değer kattığı” görüşü çoğunlukla fabrikanın üretim alanı ile sınır komşuluğu bulunmayan Şeker, Alavardı ve İhsaniye mahallelerinde yaşayanlar tarafından desteklenmiştir. "Fabrikanın içinde yer alan ağaçlarla çevreyi güzelleştirdiği” yönündeki görüş ise gürültü, kötü koku ve ulaşım vb. çevre sorunundan şikayetçi durumdaki fabrika alanı komşuluğundaki Alavardı ve Melikşah mahallelerinde daha çok desteklenirken, fabrika alanına en uzak mahalle konumundaki Hocacihan mahallesinde bu görüş desteklenmemiştir.

"Fabrikanın çevreyi korumak adına gereken önlemleri aldığı" yönündeki değerlendirmeler $\left[x^{2}=43,134, d f=24\right.$, $p=0,010 \leq 0,05]$ ile "fabrikanın çevreye olan olumsuz etkileri nedeniyle şehir dışına çıkarılmasını" isteyenler $\left[x^{2}=44,969, d f=30, p=0,039 \leq 0,05\right]$ ve "fabrikanın pek çok insana iş imkânı sağlaması nedeniyle hep yerinde kalması gerektiği” $\left[x^{2}=127,821, d f=30, p=0,000 \leq 0,05\right]$ görüşüne karşı çıkanlar mahalle bazında değişim göstermektedir: Alavardı, Melikşah ve Şeker mahallelerinde oturan katılımcılar tarafından fabrikanın çevreyi korumak adına gereken önlemleri aldığı daha çok düşünülürken, Selçuk mahallesinde oturanlar çevresel önlemlerin alınmamasından en çok şikayetçi olan katılımcılardır. Buna karşın çevresel önlemlerin alındığını düşünenler de dahil fabrika alanına en yakın konumdaki bu beş mahallede yaşayan katılımcılar (sırasıyla Melikşah, Selçuk, Hocacihan, Şeker ve Alavardı mahalleleri) "fabrikanın çevreye olan olumsuz etkileri nedeniyle şehir dışına çıkarılması gerektiğini” daha çok savunmuşlardır. "Fabrikanın pek çok insana iş imkânı sağlaması nedeniyle hep yerinde kalması gerektiğì" görüşüne karşı çıkanlar ise daha çok Selçuk ve Hocacihan mahallelerinde yaşayanlar olmuştur. Bu iki mahalle kentsel dönüşüme konu edilen, yaşanabilirliği arttırmak için yeni çehreler kazanan mahallelerdir.

Fabrikanın şehir dışına taşınması halinde alanda yer alabilecek büyük bir festival/fuar alanı $\left[x^{2}=49,043, d f=30\right.$, $p=0,016 \leq 0,05]$, park (spor, piknik, oyun alanı vb.) $\left[x^{2}=46,286, d f=24, p=0,004 \leq 0,05\right]$, alışveriş merkezi $\left[x^{2}=53,159\right.$, $d f=30, p=0,006 \leq 0,05]$, sosyo-kültürel alan (kongre merkezi, sinema, tiyatro vb.) $\left[x^{2}=44,911, d f=30, p=0,039 \leq 0,05\right]$, kent havasını temizleyecek bir ağaçlandırılacak alan $\left[x^{2}=77,392, d f=30, p=0,000 \leq 0,05\right]$, yüksek katlı konut bölgesi $\left[x^{2}=59,249, d f=24, p=0,000 \leq 0,05\right]$ vb. kullanımlara ilişkin öneriler de mahalle bazlı değişim göstermektedir: Fabrikanın şehir dışına taşınması halinde alanın festival /fuar alanı olarak düzenlenmesi Melikşah, Alavardı, Şeker ve İhsaniye mahallelerinde yaşayanlar tarafından daha çok istenmektedir. Alanda spor, piknik, oyun alanı vb. kullanımları içeren park fonksiyonu ise Melikşah ve Şeker mahallelerinde daha çok desteklemektedir. Âtıl kalacak alanda bir alışveriş merkezi düzenlemesine Selçuk mahallesi dışındaki mahallelerde sıcak bakılmıştır. Melikşah, Alavardı ve Şeker mahalleleri alanda kongre merkezi, sinema, tiyatro vb. kullanımları içeren bir sosyo-kültürel alan fonksiyonunu daha çok olarak desteklemiştir. Kent havasını temizleyecek bir ağaçlandırılacak alan önermesini ise diğer örneklem alanlarına nazaran fabrika alanına daha uzak olan Nişantaş mahallesi daha az desteklemiştir. Fabrikanın şehir dışına taşınması halinde alanın yüksek katlı konut bölgesi haline getirilmesi ise 2-3 katlı yapılaşmanın kısmen çok katlı yapılaşmaya dönüşmekte olduğu Alavardı mahallesinde daha çok desteklenmiş, Hocacihan mahallesinde daha az desteklenmiştir.

Fabrikaya daha yakın mesafede bulunan mahallelerde yaşayan katılımcılar fabrikanın şehir dışına taşınması halinde oturdukları evin ve bölgenin daha da değer kazanacağını düşünürlerken, fabrikaya nispeten daha uzak olan Nişantaş mahallesinde yaşayanlar bu görüşe katılmamaktadır $\left[x^{2}=37,210, d f=24, p=0,042 \leq 0,05\right]$. Fabrikanın kaldırılması ile bulunulan çevrede kiraların ve ev fiyatlarının artacağını düşünenler ise fabrikanın kuzey komşuluğundaki Selçuk mahallesinde daha ağırlıklıdır $\left[x^{2}=140,212, d f=30, p=0,000 \leq 0,05\right]$.

Bulunulan mahallede yaşamaktan memnun olma düzeyi "oturulan evin fabrika alanına uzaklı̆̆ı", "fabrikadan kaynaklı çevre kirliliğinin (is, çöp vb.) bulunma durumu” ve "fabrikanın çevreye olan olumsuz etkileri nedeniyle şehir dışına çıkarılması talebi” değişkenlerine bağlı değildir. Bulgular çevresel kirliliğin fabrika alanına yakın mahalleler kadar uzak mahallelerde de hissedilebildiğini; yayılı kaynak kirliliğine bağlı çevresel dışsallıklarla karşı karşıya kalabilen 
katılımcıların benzer oranlarda fabrikanın çevreye olan olumsuz etkileri nedeniyle şehir dışına çıkarılmasını gerekli gördüklerini ortaya koymaktadır. Bununla birlikte, yakın mesafede fabrikadan kaynaklı daha çok gözlenen çevresel sorunlar gürültü kirliliği $\left[x^{2}=41,308, d f=25, p=0,021 \leq 0,05\right]$, koku sorunu $\left[x^{2}=51,295, d f=25, p=0,001 \leq 0,05\right]$ ve trafik sorunu $\left[x^{2}=38,817, d f=25, p=0,038 \leq 0,05\right]$ olmuştur.

Fabrikanın çevreye olan olumsuz etkileri nedeniyle şehir dışına çıkarılmasını önerenler arasında "bulundukları mahallede yaşamaktan memnun olma düzeyi" ile "fabrikadan kaynaklı is, çöp vb. çevre kirliliğinin bulunma durumu" değişkenleri ilişkili değildir. Bu durum katılımcıların bireysel memnuniyet veya memnuniyetsizlikten ziyade genel bir alan kullanım uygunluğu açısından fabrikayı kent içi bir alan kullanımı olarak görmediklerini göstermektedir. Bunun yanı sıra şeker fabrikasının yakın çevresinde fabrikadan kaynaklı gürültü sorunu $\left[x^{2}=60,140, d f=25, p=0,000 \leq 0,05\right]$, koku sorunu $\left[x^{2}=61,254, d f=20, p=0,000 \leq 0,05\right]$, trafik sorunu $\left[x^{2}=603,994, d f=25, p=0,000 \leq 0,05\right]$ yaşayanlar ile fabrikanın Konya halkının yaşam kalitesini azalttığı görüşünde olanlar fabrikanın kent dışı bir konuma taşınması önermesini daha çok desteklemişlerdir $\left[x^{2}=136,318, d f=20, p=0,000 \leq 0,05\right]$. Bu bulgu bulunulan mahallenin yaşam kalitesini arttıran yüksek erişilebilirlik ve donatı imkanlarına (açık yeşil alan, eğitim, sağlık, sosyo-kültürel alan, komşuluk ünitesi bazlı alışveriş olanakları vb.) rağmen deneyimlenen fabrika kaynaklı olumsuzlukların (gürültü, koku ve trafik sorunu vb.) katılımcıların yaşam kalitesini azalttı̆̆ını açıkça göstermektedir.

\section{SONUÇ:}

Dinamik kentleşme süreçlerinde kent içinde kalmış sanayi alanları, çevreyi korumaya dönük önlemlerin alınmaması ve uygun teknolojilerin kullanılmaması halinde yakın konumdaki konut alanlarında yaşayanlar ağırlıklı olmak üzere kenti ve kentliyi sosyal-ekonomik ve çevresel bağlamda olumsuz etkileyebilmektedir. Yerleşim alanları içerisinde kalan sanayi alanlarından kaynaklı bu olumsuzluklardan çevresel kalitenin azalması ise sosyal ve ekonomik sonuçları da olan önemli bir sorunsaldır. Bu nedenle sanayi alanlarına ilişkin konum ve faaliyet özellikleri doğrudan veya dolaylı olarak yaşamı ve yaşam kalitesini etkilemesi nedeniyle kritik konulardır.

Konya Şeker Fabrikası 1954 yılından günümüze kadar sadece Konya kenti ölçeğinde değil, bölgesel ve ulusal ölçekte ekonomik büyüme, istihdam ve iş fırsatları gibi birçok başarıya yol açmıştır. Fakat kurulduğu dönemde yerleşimlerden uzak bir konumda iken kentteki nüfus/kentsel yerleşik alan artışı beraberinde kent içi bir sanayi alanı haline gelen fabrika alanı aynı zamanda yakın çevresinde çevresel kaliteyi, dolayısıyla kentlinin yaşam kalitesini düşürebilecek çeşitli çevresel ve sosyal sorunlara da yol açmıştır. Konya Şeker Fabrikası'nın çevresel kalite bağlamında kente ve kentliye etkilerini ve kentsel konfor düzeyini fabrika alanının yakın çevresinde yaşayan yerleşik halkın perspektifinden araştıran bu nicel ve nitel çalışmanın sonuçları da alana ilişkin önceki bilimsel araştırma bulgularını destekler niteliktedir.

Fabrika alanı ile konumsal yakınlıkları nedeni ile olası çevresel dışsallıklara ağırlıklı olarak maruz kaldıkları varsayılan konut bölgelerinde (Alavard1, Melikşah, Hocacihan, İhsaniye, Nişantaş, Selçuk ve Şeker Mahalleleri’nde) gerçekleştirilen saha çalışması bulguları katılımcıların fabrikanın ekonomik faaliyetlerinden genelde memnun olduklarını, ancak alanın yakın çevresinde hava kalitesinin çok düşük olduğunu, katılımcıların fabrika alanından kaynaklı çevresel rahatsızlıklarının (hava, gürültü, çevre ve görüntü kirliliği vb.) ve sağlık kaygılarının oldukça fazla olduğunu göstermektedir. Fabrikadan yayılan şeker pancarı kokusu ise kentsel mekânda konforu azaltan (nefes alamama, evin dışında zaman geçirememe, alanda dolaşım sürelerini/fiziksel aktiviteyi kısıtlama, çamaşır kurutamama, evi havalandıramama vb.) öncelikli bir sorun olarak karşımıza çıkmaktadır. Bu tespitler doğrultusunda fabrikanın ekonomik büyümesi birlikteliğinde aldığı çevresel tedbirlerin halk tarafından yetersiz görüldüğü anlaşılmaktadır. Önemli miktarda nüfusu yakından ilgilendiren bu sorunların çözümüne yönelik uygulama stratejilerinin fabrika yöneticileri ve kentteki planlama otoriteleri (Meram ilçesi ve Büyükşehir Belediyesi bazında) ile halkın da katıldığı katılımcı platformlarda geliştirilmeleri gereklidir. Bu araştırma sonuçları çevresel kalite sorunlarına ilişkin halkın yaklaşımlarını/önceliklerini ve alanda çevresel kaliteyi arttırmaya yönelik önerilerini bilimsel bir metotla bir araya getirmesi ve sunması yönü ile bu tür katılımcı platformlarda değerlendirilebilecek önemli bir argüman niteliğindedir.

Araştırma bulguları günümüzde yerleşim alanları içerisinde kalan Konya Şeker Fabrikası'nın kent çevresinde oluşturulan sanayi alanlarına taşınmasının; (1) kentlinin sağlık koşullarını risk altında olmaktan çıkarma, (2) halkın bulunulan alandaki çevre koşullarını (hava kirliliği, gürültü, çevre kirliliği ve görsel kirlilik vb.) iyileştirme, (3) kentsel 
alana ilişkin ulaşım yoğunluğu, güvenlik vb. olumsuzlukları bertaraf edebilmek için gerekli ve faydalı bir yaklaşım olduğunu açıkça göstermektedir. Ayrıca Konya Mahalli Çevre Kurulu'nun fabrika alanının kent çeperine taşınmasına ilişkin kararı ile imar planında fabrika alanının park olarak gösterilmesi ile de fabrika alanının merkez dışına alınması ve dönüştürülmesinin yerel otoritelerin gündeminde olduğu anlaşılmaktadır. Zira fabrika alanının kent çeperine taşınması sadece belirtilen çevresel ve kentsel risklerden sakınmayı önemseyen bir yaklaşım olmaktan çok, kent ve kentli için çevre ve ekonomi arasında dengeyi sağlamada ve sorumlu şehircilik anlayışı çerçevesinde olumsuzlukları firsata çevirmede planlama ve yerel yönetim otoritelerine önemli bir araç olarak değerlendirilebilir.

Araştırma sonuçları âtıl kalacak alanın tasarrufunda bireysel menfaatlerden ziyade kamusal menfaatin göz önüne alınması gerektiğine işaret etmektedir. Bu noktada kent merkezinde erişilebilir bir konumda, geniş bir arazi üzerine kurulmuş olan, düşük yoğunluklu yerleşimler ile yüksek yoğunluklu kentsel dönüşüme konu edilen konut bölgeleri komşuluğunda bulunan fabrika alanının taşınmasıyla âtıl kalacak alanın değişen dönüşen kent ile kentlilerin ihtiyaç duydukları sosyo-kültürel eylemlere karşılık verecek kamusal mekân (kent parkı, millet bahçesi, piknik alanı, çocuk parkı, rekreasyon alanı vb. büyük açık-yeşil alan kullanımları, sosyo-kültürel alan, eğitim alanı, vb.) üretimine konu edilmesi kentte çevre kalitesini ve kentsel konforu arttırmada, kentsel mekanı çekici ve yaşanabilir kılmada olumlu katkılar sağlayabilir. Bu işlev dönüşümü esnasında kent belleğinde yer alan fabrika izlerinin korunması ise kültürel sürekliliği sağlamada önemli bir başarı ölçütü durumundadır. Son olarak çalışma bulguları Konya Şeker Fabrikası'nın çevresel kaliteye olumsuz etkilerini anlamada ve bertaraf etmede kentteki yöneticilere ve planlama mesleğine katk1 sağlayacak niteliktedir.

\section{Etik Standart ile Uyumluluk}

Çıkar Çatışması: Yazar herhangi bir çıkar çatışmasının olmadığııı beyan eder.

Etik Kurul İzni: Bu çalışma için etik kurul iznine gerek vardır. Ancak nicel ve nitel veri toplamada anket yöntemini kullanan nicel ve nitel bir yaklaşımla gerçekleştirilen bu çalışmada verilerin toplanması Etik Kurul Onay zorunluluğundan önceki tarihte (2019 yılında) gerçekleştirilmiştir. Anket sırasında ilgili katılımcılardan (bireylerden) gerekli izinler alınmış; gönüllü̈lük esas olmuştur.

Finansal Destek: Bulunmamaktadır.

Teşekkür: Çalışmaya esas teşkil eden anket sorularının geliştirilmesine yönelik pilot uygulaması aşaması Necmettin Erbakan Üniversitesi Şehir ve Bölge Planlama Bölümü ögrencileri Amine İçen, Beyza Gürçay, Dilek Ağlamaz, Hidayet Güneş ve Ömer Taşpunar'ın desteğiyle 100 derinlemesine halk görüşmesi şeklinde gerçekleştirilmiş; pilot uygulama sonuçları 28 Nisan - 01 Mayls 2018 tarihinde Alanya'da (Antalya) düzenlenen III. INES Uluslararası Eğitim ve Sosyal Bilimler Kongresi'nde "Sosyal ve Çevresel Etkiler Bağlamında Kent İçi Sanayi Alanlarının Irdelenmesi” başlıklı bildiri kapsamında sunulmuştur. Pilot uygulama sonrası edinilen tecrübelerle içeriği ve soru ölçekleri geliştirilerek nihai halini alan ve bu çalışmaya konu olan anket föylerinin halka uygulanması aşamasında ise Necmettin Erbakan Üniversitesi Şehir ve Bölge Planlama Bölümü 2019-2020 Ĕ̆itim-Öğretim Yılı 1. sınıf ögrencileri özveri ile destek olmuşlardır.

\section{KAYNAKÇA:}

\section{Kitaplar:}

Atkins, P., Marson, R. \& Brann, B. (2015). State of Australian cities 2014-2015 progress in Australian regions. Department of Infrastructure and Regional Development, Commonwealth of Australia. https://www.infrastructure.gov.au/infrastructure/pab/soac/files/2015_SoAC_full_report.pdf

\section{Raporlar:}

Karyeyen, S., Aksoy, M.H., Özgören, M. \& Koçak, S. (2012). Konya sanayisinde enerji verimliliği (Mevlana Kalkınma Ajansı Bölgesel Araştırma Raporları Serisi, Yayın No:5). Konya.

Konya Büyükşehir Belediyesi. (2016). 1/100.000 ölçekli Konya çevre düzeni planı plan açıklama raporu (Egeplan \& Modül Planlama). Konya. 
Krekel, C. \& MacKerron, G. (2020). How environmental quality affects our happiness, in World Happiness Report 2020 (WHR 2020), pp. 94-111, https://happiness-report.s3.amazonaws.com/2020/WHR20_Ch5.pdf

Lowe, M., Whitzman, C., Badland, H., Davern, M., Hes, D., Aye, L., Butterworth, I. \& Giles-Corti, B. (2013). Liveable, healthy, sustainable: What are the key indicators for Melbourne neighbourhoods? (Research Paper 1). University of Melbourne, Place, Health \& Liveability Research Program. https://communityindicators.net/resources/liveablehealthy-sustainable-what-are-the-key-indicators-for-melbourne-neighbourhoods/

Parkinson, M., Champion, T., Simmie, J., Turok, I., Crookston, M., Yeang, L.D., Katz, B., Park, A., Berube, A., Coombes, M., Dorling, D., Evans, R., Glass, N., Hutchins, M., Kearns, A., Martin, R. \& Wood, P. (2006). State of the English cities: A research study (Volume 1). Office of the Deputy Prime Minister (ODPM). ISBN: 10 1-85112845-X, 13 978185112845-7. London.

Yeang, L.D. (2006). Quality of place: The north's residential offer; Leeds city region. Llewelyn Davies Yeang Architecture Planning Design.

\section{Makaleler:}

Altanlar, A., Sınmaz, S. \& Çakıroğlu, A. (2020). The role of creative industries on urban transformation: a project experience in Antalya Weaving Factory Area. Kent Akademisi, Volume 13 (41), Issue 1, 123-145.

Carmona, M. \& C. de Magalhaes (2009). Local environmental quality: establishing acceptable standards in England. Town Planning Review, 80(4-5): 517-548.

Çelik, S., Çankaya, Ş.F. \& Küçüksille, E.U. (2017). Kentlerde çevresel kalite endeksini değerlendirmek için bir sistem gerçekleştirimi: Isparta ili örneği. MAKÜ-Uygulamalı Bilimler Dergisi, 1(1), 1-8.

Çiftci, Ç., Dursun, Ş., Levend, S. \& Kunt, F. (2013). Topoğrafik yapı, iklim şartları ve kentleşmenin Konya'da hava kirliliğine etkisi. Avrupa Bilim ve Teknoloji Dergisi, 1(1), 19-24.

Dalkılıç, E. \& Dursun, Ş. (2019). Konya gürültü kirliliği ve eylem planlarının yorumlanması. Düzce Üniversitesi Bilim ve Teknoloji Dergisi, 7, 38-51.

Dede, O. M. \& Şekeroğlu A. (2019). Sağlıklı kent kavramı için nüfus kriterinin önemi. Kent Akademisi, 12 (4), 703 713.

Dissanayake, D., Morimoto, T., Murayama, Y., Ranagalage, M. \& Perera, E. (2020). Analysis of life quality in a tropical mountain city using a multi-criteria geospatial technique: A case study of Kandy City, Sri Lanka. Sustainability, 12(7), 2918.

Durduran, S.S. \& Durduran, Y. (2009). Coğrafi bilgi sistemi yardımıyla kalp ve solunum yolu hastalarının mekansal dağılımının belirlenmesi: Konya örneği. S. U. Mühendislik-Mimarlık Fakültesi Dergisi, 24(3), 19-28.

Dursun, Ş., Özdemir, C., Karabörk, H. \& Koçak, S. (2006). Noise pollution and map of Konya city in Turkey. International Environmental Application \& Science, 1(1-2), 63-72.

Esen, F. \& Toprak, D. (2017). Astım-kardiyolojik hastalık profillendirmesi ve hava kalitesi değerlendirmesi. Sakarya Tip Dergisi, 7(1), 1-9.

Hsueh, S-L. \& Lin, Y-J. (2018). Critical success factors of the urban environmental quality. Ekoloji, 27(106), $217-222$.

Kanbak, A. (2013). İstanbul sanayisinin Kocaeli iline mekânsal etkileri. AİBÜ Sosyal Bilimler Enstitüsü Dergisi, 13(2), 275-300.

Kara, G., Bozkurt, Ç. \& Çay, Y. (2019). Konya'da hava kirliliği konusunda farkındalık düzeyinin belirlenmesi. Ulusal Çevre Bilimleri Araştırma Dergisi, 2(2), 91-94.

Kaya, S., Yerli, Ö. \& Döner, S. (2015). Endüstriyel alanların endüstriyel parklara dönüşümü. Düzce Üniversitesi Bilim ve Teknoloji Dergisi, 3 (2015), 518-534.

Koç, I. (2021) Using Cedrus atlantica's annual rings as a biomonitor in observing the changes of Ni and Co concentrations in the atmosphere, Environmental Science and Pollution Research. Doi:10.1007/s11356-02113272-3. 
Leby, J.L. \& Hashim, A.H. (2010). Liveability dimensions \& attributes: their relative importance in the eyes of neighbourhood residents. Journal of Construction in Developing Countries, 15(1), 67-91.

Li D., Chen Y., Chen H., Kai G., Hui C.M. \& Yang J (2016) Assessing the integrated sustainability of a public rental housing project from the perspective of complex eco-system. Habitat International, 53, 546-555. https://doi.org/10.1016/j.habitatint.2016.01.001

Mohammadi, A.A., Zarei, A., Esmaeilzadeh, M., Taghavi, M., Yousefi, M., Yousefi, Z., Sedighi, F. \& Javan, S. (2020). Assessment of heavy metal pollution and human health risks assessment in soils around an industrial zone in Neyshabur, Iran. Biological Trace Element Research, 195, 343-352. https://doi.org/10.1007/s12011-019-01816-1

Önder, S. \& Konakl1, N. (2002). Görsel kirlilik ve Konya kenti örneğinde incelenmesi üzerine bir araştırma. S. Ü. Ziraat Fakültesi Dergisi, 16(30), 28-37.

Önder, S., Dursun, S., Gezgin, S. \& Demirbaş, A. (2007). Determination of heavy metal pollution in grass and soil of city centre green areas (Konya, Turkey). Polish Journal of Environmental Studies, 16(1), 145-154.

Özgür Güler, E. \& Börüban, C., (2019). Çevresel kalite üzerinde endüstrinin ve ölçek etkisinin incelenmesi. Çukurova Üniversitesi İ̈BF Dergisi, 23(1), 63-75.

Sarı, V.İ. \& Kındap, A. (2018). Türkiye'de kentsel yaşam kalitesi göstergelerinin analizi. Sayıştay Dergisi, 108, 39-72.

Silva, L.T. \& Mendes, J.F.G. (2012). City noise-air: An environmental quality index for cities. Sustainable Cities \& Society, 4, 1-11.

Streimikiene, D. (2015). Environmental indicators for the assessment of quality of life. Intellectual Economics, 9, 6779.

Tapsuwan, S., Mathot, C., Walker, I. \& Barnett, G. (2018). Preferences for sustainable, liveable and resilient neighbourhoods and homes: a case of Canberra, Australia. Sustainable Cities and Society, 37, 133-145.

Yüzer, A.Ş. \& Giritlioğlu, C. (2003). Sanayi alanları yeni düzenleme stratejileri-İstanbul örneği. itüdergisi/a mimarlık, planlama, tasarım, 2(1), 119-127.

Zeren, F. \& K1lınç Savrul, B. (2012). Türkiye'de şehirleşmeyi etkileyen faktörler: mekânsal ekonometri analizi. Journal of Yasar University, 28(7), 4749-4765.

\section{Bildiriler:}

Türkoğlu, H., Bölen, F., Baran, K.P. \& Robert Marans, R. (2006, July 2-5). Measuring quality of urban life: findings from Istanbul metropolitan study [Paper presentation]. ENHR conference Housing in an expanding Europe: theory, policy, participation and implementation, Ljubljana, Slovenia, 2-5 July 2006.

Ünal, Ç. \& Yücel, B. (2017). Kent içi sanayilere yerel halkın yaklaşımı [Sözlü Bildiri]. Proceedings Book of 2nd International Scientific Researches Congress on Humanities and Social Sciences (IBAD-2017), Istanbul,Turkey, 62-73. ISBN: 978-605-66529-0-5.

Yaşar, S. \& Şevik, H. (10-12 Eylül 2003). Konya'da hava kirliliğinin değerlendirilmesi [Sözlü Bildiri]. Yanma ve Hava Kirliliği Kontrolu VI. Ulusal Sempozyumu, İzmir, 391-402.

\section{Tezler:}

Allen, N.M. (2016). Quality of urban life and intensification: Understanding housing choices, trade-offs, and the role of urban amenities [Doctoral Thesis, University of Auckland].

Salihoğlu T. (2016). Kentsel yaşam kalitesinin yükseltilmesinde boş zaman aktivitelerinin rolü: İstanbul örneği [Doktora Tezi, İstanbul Teknik Üniversitesi].

Tolga, H.B. (2006). Endüstriyel alanların dönüşümü, kentsel mekâna etkileri: Beykoz Kundura ve Deri Fabrikası için bir dönüşüm senaryosu [Yüksek Lisans Tezi, Yıldız Teknik Üniversitesi].

Yaman, M. (2005). Kent planlamasında organize sanayi bölgelerinin yeri: Kütahya örneği [Yüksek Lisans Tezi, Ankara Üniversitesi] 


\section{Web Siteleri:}

Architects Council of Europe-ACE. (2019). Achieving quality in the built environment. https://www.acecae.eu/fileadmin/New_Upload/_15_EU_Project/Creative_Europe/Conference_Quality_2019/Inn_Stat_EN_FINA L.pdf, Erişim Tarihi: 15.06 .2020 .

ODPHP (Office of Disease Prevention and Health Prmotion) (2020). Environmental quality. https://www.healthypeople.gov/2020/leading-health-indicators/2020-lhi-topics/Environmental-Quality, Erişim Tarihi: 26.03.2021.

Url 1: 15.03.2011 tarih ve 2011/02 sayılı Konya Mahalli Çevre Kurulu kararı, https://www.konya.bel.tr/sayfadetay.php?sayfaID=377, Erişim Tarihi: 24.09.2020.

Url 2: 29.01.2013 tarih ve 2013/01 sayıl1 Mahalli Çevre Kurulu karar1, https://webdosya.csb.gov.tr/db/konya/icerikbelge/icerikbelge1100.pdf, Erişim Tarihi: 24.09.2020.

Url 3: http://www.konyaseker.com.tr/tr/icerik/detay/2113/konya-seker, Erişim Tarihi: 27.09.2020.

Url 4: http://www.konyaseker.com.tr/tr/icerik/detay/2034/konya-merkez-kampusu, Erişim Tarihi: 27.09.2020.

Url 5:

https://earth.google.com/web/search/Sel\%C3\%A7uklu\%2fKonya/@37.85634234,32.57769893,1021.43901808a, 75817.18052823d,35y,0h,0t,0r/data=CigiJgokCSJupVBC-UJAEQ75fCQEz0JAGVxFMZr1h0BAIfXEPp, Erişim Tarihi: 25.04.2021.

Url 6: http://www.konyaseker.com.tr/tr/icerik/detay/2034/konya-merkez-kampusu, Erişim Tarihi: 27.09.2020.

Url 7: https://www.surveysystem.com/sscalc.htm, Erişim Tarihi: 10.06.2020.

Url 8: Ki-Kare testi: anlamı, uygulamaları ve kullanımları. https://tr.triangleinnovationhub.com/chi-square-testmeaning, Erişim Tarihi: 27.09.2020.

Url 9: http://www.istatistikanaliz.com/ki-kare_analiz_testi.asp, Erişim Tarihi: 01.11.2010. 